Provided for non-commercial research and education use. Not for reproduction, distribution or commercial use.

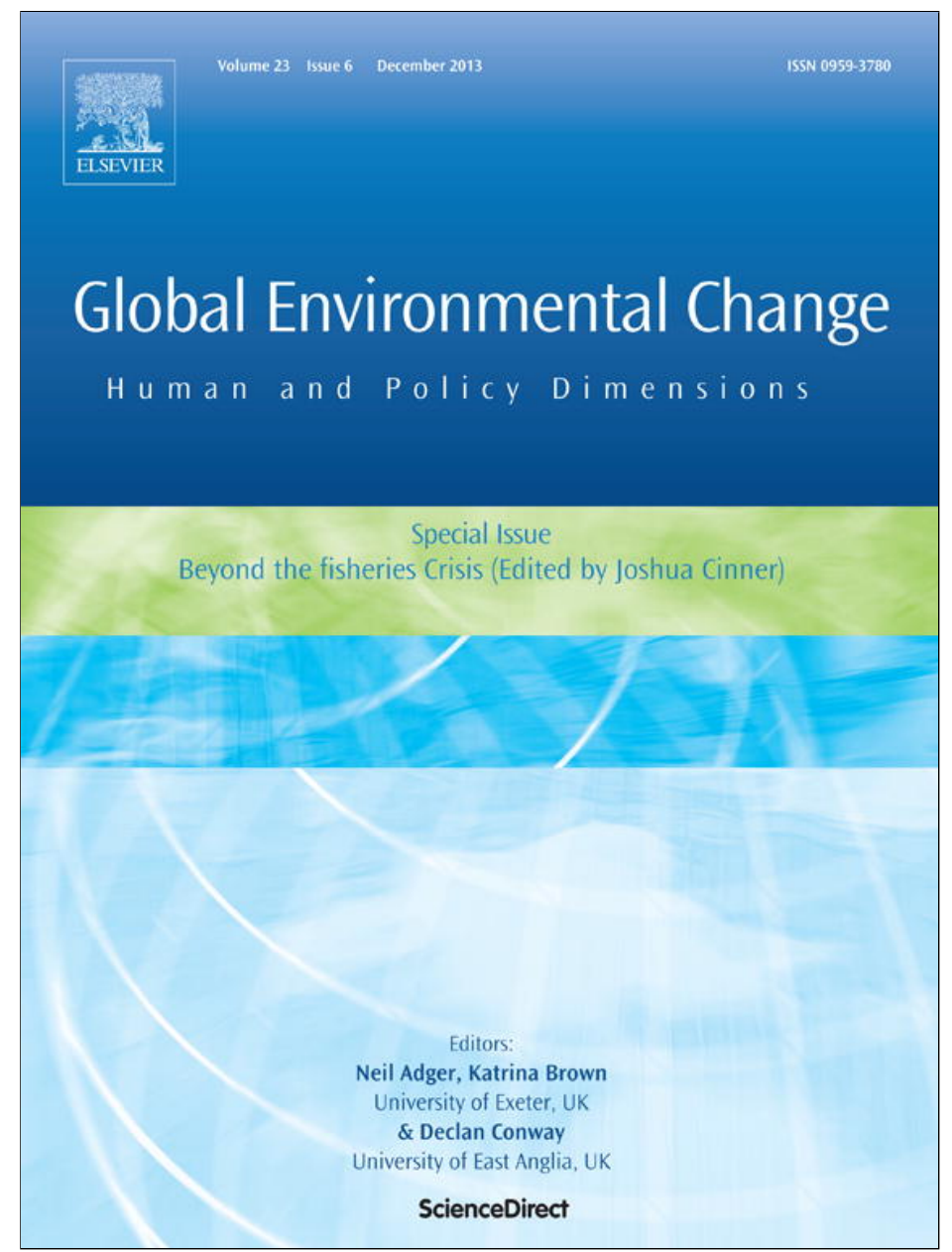

This article appeared in a journal published by Elsevier. The attached copy is furnished to the author for internal non-commercial research and education use, including for instruction at the authors institution and sharing with colleagues.

Other uses, including reproduction and distribution, or selling or licensing copies, or posting to personal, institutional or third party websites are prohibited.

In most cases authors are permitted to post their version of the article (e.g. in Word or Tex form) to their personal website or institutional repository. Authors requiring further information regarding Elsevier's archiving and manuscript policies are encouraged to visit:

http://www.elsevier.com/authorsrights 


\title{
The social-ecological system framework as a knowledge classificatory system for benthic small-scale fisheries
}

\author{
Xavier Basurto $^{\mathrm{a}, *}$, Stefan Gelcich ${ }^{\mathrm{b}, \mathrm{c}, 1}$, Elinor Ostrom ${ }^{\mathrm{d}, 2}$ \\ ${ }^{a}$ Division of Marine Science and Conservation, Nicholas School of the Environment, Duke University, 135 Duke Marine Lab Road, Beaufort, NC 28516, USA \\ ${ }^{\mathrm{b}}$ Centro de Conservación Marina, Departamento de Ecología, Facultad de Ciencias Biológicas, Pontificia Universidad Católica de Chile, Alameda 340, Santiago, \\ Chile \\ ${ }^{c}$ Laboratorio Internacional en Cambio Global, Consejo Superior de Investigaciones Científicas (CSIC), Esporles, Spain \\ ${ }^{\mathrm{d}}$ The Vincent and Elinor Ostrom Workshop in Political Theory and Policy Analysis, Indiana University, 513 North Park Avenue, Bloomington, IN 47408, USA
}

\section{A R T I C L E I N F O}

\section{Article history:}

Received 18 July 2012

Received in revised form 3 July 2013

Accepted 4 August 2013

\section{Keywords:}

Benthic small-scale fisheries

Social-ecological system (SES) framework

Mexico

Chile

Human dimensions

\begin{abstract}
A B S T R A C T
Ostrom proposed the underpinnings of a framework for the systematic study of the governance of complex social-ecological systems. Here we hypothesize that Ostrom's social-ecological system framework can be useful to build a classification system for small-scale benthic fisheries, regarding their governance processes and outcomes. The purpose of this paper is to contribute to knowledge accumulation of benthic fisheries. To tailor the framework, we relied on discussions among experts and a systematic literature review of benthic fisheries from 1980 to 2010. This literature review helped us refine variable definitions and provide readers with illustrative reference papers. We then illustrate the approach and its potential contributions through two studies of the emergence of self-organization in Mexico and Chile. We highlight synthetic lessons from the cases and the overall approach as well as reflect on remaining challenges to the development of a social-ecological system framework as a diagnostic tool for knowledge accumulation and synthesis.
\end{abstract}

(c) 2013 Elsevier Ltd. All rights reserved.

\section{Introduction}

Small-scale fisheries are increasingly conceptualized as integrated social-ecological complex adaptive systems in part because of the type of problems they exhibit (Berkes, 2006, 2011; Folke et al., 2005; Gelcich et al., 2010; Mahon et al., 2008; McConney and Charles, 2010; Wilson, 2006). These problems, such as avoiding overexploitation, are rarely attributable to a single cause (Anderies et al., 2007). As Holling et al. (1998, p. 352) state:

Characteristically, these problems tend to be systems problems, where aspects of behavior are complex and unpredictable and where causes, while at times simple (when finally understood), are always multiple. They are non-linear in nature, cross-scale in time and in space, and have an evolutionary character. This is true for both natural and social systems. In fact, they are one system, with critical feedbacks across temporal and spatial scales.

\footnotetext{
* Corresponding author. Tel.: +1 252504 7540; fax: +1 2525047648.

E-mail addresses: xavier.basurto@duke.edu (X. Basurto), sgelcich@bio.puc.cl (S. Gelcich), workshop@indiana.edu (E. Ostrom).

${ }^{1}$ Tel.: +56 23541914 .

2 Tel.: +1 812855 0441; fax: +1 8128553150
}

The role of multiple causes has also been described by Ostrom (2005) when discussing the behavior of social rule systems and the governance outcomes they produce. Sets of rules interact in complex patterns, and the addition or removal of a particular rule may affect the interactions of the rest of the set and thus the governance outcome (Cox, 2011). Scholars studying small-scale fisheries have made great strides toward identifying key processes affecting their governance (Castilla and Defeo, 2001; Cinner et al., 2007; Defeo and Castilla, 2005; Gelcich et al., 2010; Hilborn, 2007; Orensanz et al., 2013; Pauly, 2006). However, the role of rule configurations in social-ecological interactions, and how it challenges our ability to establish causal mechanisms linking conditions and governance outcomes, has received considerably less attention. One of the many challenges of understanding what configurations of conditions may lead to particular governance outcomes, consists of devising a tractable way to organize and document them. Ontologies, or systems of classification, can serve these functions. For instance, the Latin alphabet constitutes a relatively simple system of classification, and its dictionary serves as the framework in which empirical configurations of this ontology are expressed for a particular language. In this example, past and future books that have or will be written on diverse topics are expressions of how systems of classification allow knowledge accumulation and future 
innovation. Using the concept of ontologies, the pertinent question for SESs is then: How can the SES research agenda develop an approach that allows for knowledge accumulation that can inform typologies of governance arrangements for particular small-scale fishery outcomes?

In 2007, Ostrom proposed the underpinnings of a framework for the systematic study of the governance of complex SESs. Here we hypothesize that Ostrom's social-ecological system (SES) framework can be useful to build a classification system for small-scale benthic fisheries, regarding their governance processes and outcomes. The first step in this process is to develop a suite of key SES variables or processes potentially relevant to anyone considering conducting a study on benthic small-scale fisheries. This is referred to as an ontology. By analyzing the literature, this paper develops a benthic small-scale fisheries ontology. It then illustrates the use of the SES framework through two short studies concerning Mexican and Chilean benthic fisheries. Both studies focused on teasing out the underlying factors affecting the self-organization capacity of the fisheries to avoid tragedies associated with open access. We conclude with some lessons, cautionary notes, and remaining challenges for the use of the SES approach developed here.

\section{Theoretical background}

Theories of collective action and common-pool resources (CPRs) have contributed to our understanding of processes and conditions facilitating the likelihood of local self-organization (Acheson, 2003; Baland and Platteau, 1996; Berkes, 1989; Bromley et al., 1992; NRC, 1986, 2002; Ostrom, 1990, 2005), but scholars' ability to establish causal linkages among factors and determine their relevance at local contexts, and regardless of context, is still quite limited (Agrawal, 2002). Young (2002) argued for the need to develop an "institutional diagnostic" approach as a way to overcome these challenges. In medicine, doctors usually follow a diagnostic approach toward identifying a solution to a medical problem. A doctor will ask us a number of initial questions and do some regular measurements. In light of that information, the doctor proceeds down a medical ontology to ask further and more specific questions (or prescribes tests) until a reasonable hypothesis regarding the source of the problem can be found and supported. When we begin to think about a particular SES puzzle, we think about which of the attributes of a particular SES system are likely to have a major impact on particular patterns of interactions and outcomes. While each human being is unique, illnesses can be identified and diagnosed in a similar way to an entire population. A diagnostic approach for SESs should be capable of teasing out what makes each resource use problem unique and what makes each case generalizable and comparable across settings. Here we contend that the SES framework's multitiered organizational structure could be useful to develop a diagnostic approach for the study and governance of SESs (McGinnis and Ostrom, 2013; Ostrom, 2007, 2009).

The point of entry to the SES framework begins with the firsttier variables that a researcher would need to define to determine the particular focal CPR system of interest (Fig. 1): The Resource Units (RU) are part of the Resource Systems (RS), the Governance Systems (GS) define and set rules for Actors (A). All of them influence the resultant Interactions (I) and Outcomes (O) and create feedbacks. These variables (also conceptualized as processes) make up the focal CPR system that links to exogenous factors like other Related Ecosystems (ECO) and Social, Economic, and Political Settings (S).

In this paper, the Resource System (RS) is the small-scale fishery sector and the Resource Units (RU) are the benthic resources harvested by commercial fishers. The Governance System (GS) includes characteristics pertaining to central and local government and factors shaping rules and governance arrangements in Mexico and Chile. These determine incentives and behavior for Actors (A) involved in the fisheries. Such actors include local and non-local fishers, researchers, non-governmental organizations, and government officials. The Social, Economic, and Political Setting (S) is the Gulf of California in northwest Mexico, and the rural central Chilean coast. We aim to diagnose what combinations of SES variables were associated with fishers' ability to self-organize and avoid overexploiting their fisheries, and which interactions led to continued overharvesting.

Social, Economic, and Political Settings (S)

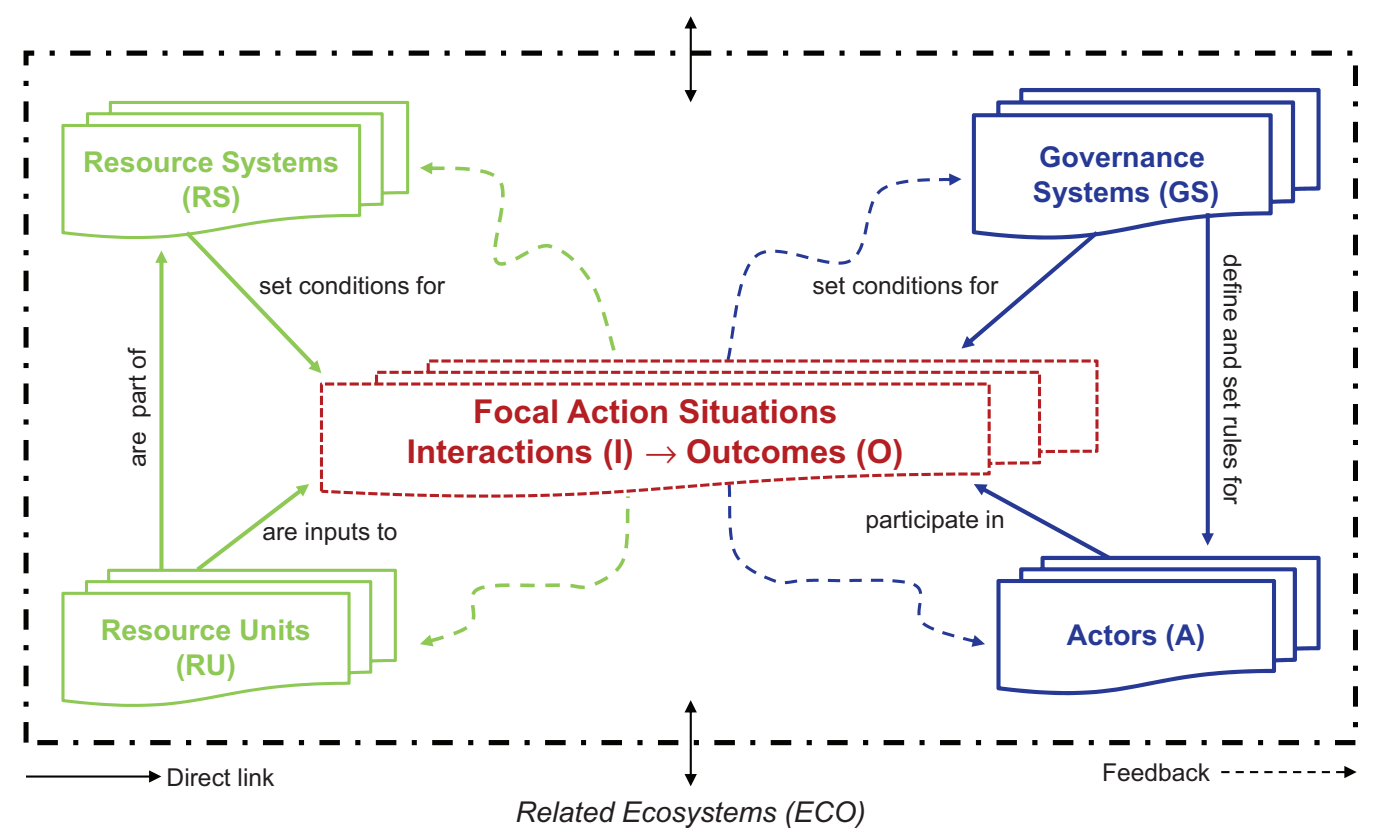

Fig. 1. Revised SES framework with multiple first-tier components. Source. McGinnis and Ostrom (2013). 
The SES framework is hierarchical in that it is multitiered. Each of the variables contained in the first tier unpacks to reveal a number of second-tier variables, which could further unpack into a third tier, and so on and so forth. Ostrom's (2009) selection of second-tier variables was based on three decades of empirical work studying CPRs (Acheson, 2003; Baland and Platteau, 1996; McKean, 1992, 2000; Ostrom, 1990; Ostrom et al., 1992; Schlager, 1994; Tang, 1992; Wade, 1994). These variables are particularly salient to tease out the likelihood that a local or self-governing association will be constituted by developing rules and norms to limit their harvesting or protect the use of the resource in some manner. However, the use of the SES framework by scholars thus far suggests its versatility to accommodate the investigation of a diversity of governance-related questions (Blanco, 2011; Cinner et al., 2012; Fleischman et al., 2010; Gutiérrez et al., 2011).

\section{Methods}

\subsection{Developing a classificatory system for benthic small-scale fisheries}

We began by updating the second-tier factors proposed by Ostrom (2009) according to recent modifications suggested by McGinnis and Ostrom (2013). We then reviewed the updated list for relevance to benthic fisheries SESs. This process resulted in the replacement or exclusion of second-tier variables in Ostrom (2009) and the development of new third-, fourth-, and fifth-tier variables presented in Table 1. For the review and development of new third-, fourth-, and fifth-tier variables, we relied on our own practical experience, the assistance of fisheries ecologists, and on a literature review on benthic small-scale fisheries using the key words "small-scale" or "artisanal." Paper selection was limited to resources harvested through diving and/or intertidal gathering on the marine benthos. Searches were conducted for the time period between 1980 and 2010, encompassing 98\% of the indexed literature on the topic. We used ISI Web of Knowledge, a major indexing database aggregate of peer-reviewed literature. For each variable in the framework, a working definition and illustrative citation is provided. Listed citations for each definition are not presented as definitive authoritative sources; they constitute illustrations of how other scholars may have applied the concept in other benthic-related published studies.

\subsection{Applying the SES framework to studies of benthic fisheries in Mexico and Chile}

We selected two benthic small-scale fishing settings in Mexico and Chile for which peer-reviewed documentation was available and for which the authors had significant first-hand knowledge. The study conducted in Mexico looked at three different fisheries (Puerto Peñasco, Kino, and the Seri) within the Gulf of California. The study conducted in Chile compared the same community in three different time periods. Both studies looked at the combination of factors that could be associated with the fishers' ability to self-organize to control access to other fishers. The main purpose of drawing on these studies was to provide an empirical example of

Table 1

Second to fifth-tier variables of an SES for benthic small-scale fisheries. Factors modified from Ostrom (2009) and specific for benthic small-scale fisheries are noted with color red and italic font. Tiers for Interactions and Outcomes are not included as they were not modified from the original.

Social, Economic, and Political Settings (S)

S1 - Economic development. S2 - Demographic trends. S3 - Political stability. S4 - Other governance systems. S5 - Markets. S6 - Media organizations. S7 - Technology

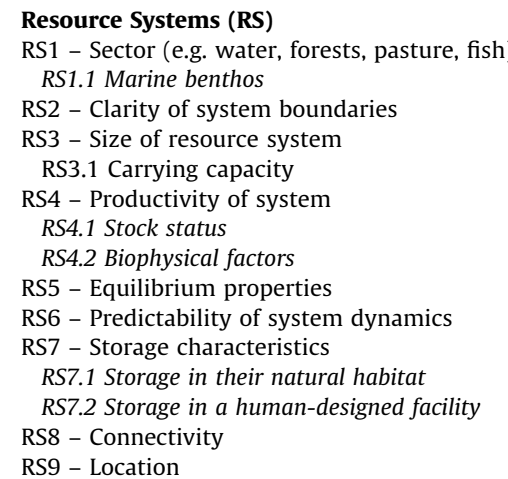

\section{Resource Units (RU)}

RU1 - Resource unit mobility

RU2 - Growth or replacement rate

RU3 - Interaction among resource units

RU3.1 Reproduction

RU3.2 Settlement

RU4 - Economic value

RU5 - Number of units

RU6 - Distinctive characteristics

RU6.1 Hatchery

RU6.2 Wild

RU7 - Spatial and temporal distribution

RU7.1 Patchy

RU7.2 Random
Actors (A)

A1 - Number of relevant actors

A2 - Socioeconomic attributes

A3 - History or past experiences

A3.1 Crisis

A3.2 Duration

A4 - Location

A5 - Leadership/entrepreneurship

A6 - Social capital

A6.1 Trust and reciprocity

A7 - Knowledge of SES/mental models

A7.1 Mechanism to share knowledge about the fishery

A8 - Importance of resource

A8.1 Economic dependence

A8.2 Cultural dependence

A9 - Technologies available

A9.1 Ownership of technology by fishers

A9.2 Homogeneity

Governance Systems (GS)
GS1 - Policy area
GS1.1 Environment
GS1.1.1 Benthic marine
GS2 - Geographic range
GS3 - Population
GS4 - Regime type
GS4.1 Democratic
GS4.2 Autocratic

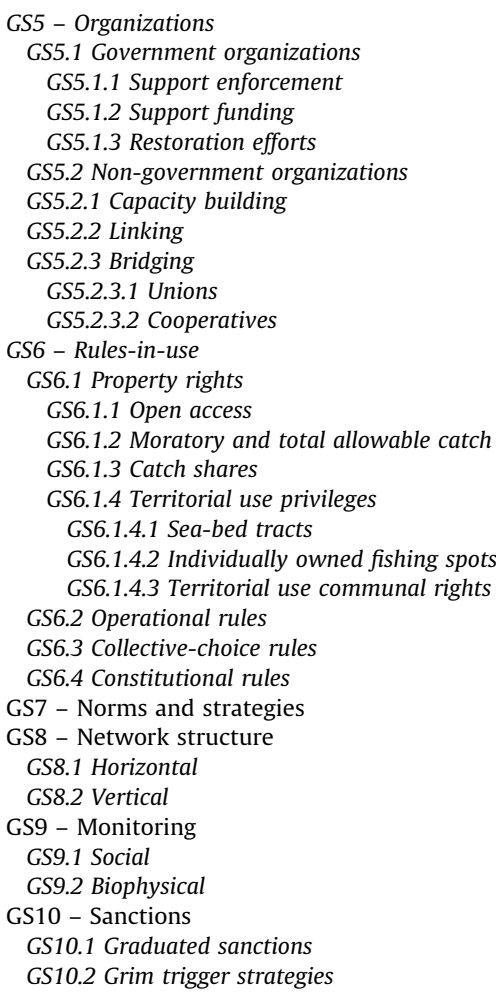


how the SES framework can be useful to analyze complex SES interactions, because it makes it feasible to keep track of how different combinations of conditions are associated with similar outcomes.

\section{Results}

4.1. Changes to the general SES framework to create a benthic fisheries SES framework

Below we provide a summary of the modifications made to the original SES general list of variables proposed by Ostrom (2009). We used Ostrom (2009) modified by McGinnis and Ostrom (2013) as a template for our benthic fisheries SES framework because their general SES framework is the most up to date. The benthic SES framework is presented in Table 1. The table is organized by: Resource Systems (RS), Resource Units (RU), Actors (A) and Governance Systems (GS). A detailed summary of the modifications is found in Appendix A, followed by Tables A.1-A.4 containing definitions and illustrative examples from the broader literature for each variable presented in Table 1 above.

The Resource System was extended to include second- and third-tier variables/processes. These tiers focus on the heterogeneity of the systems' productivity and connectivity, as these factors can drive resource availability. In addition, differences in resource storage characteristics were added. Resource Unit's characteristics have been described as important in small-scale fisheries governance. In order to acknowledge their role in determining outcomes, we added aspects of species life history traits and spatial distribution as third-tier variables/processes. There is a high diversity of governance arrangements in benthic fisheries. Thus, the development of new tiers for the Governance System was most profound in our adaptation of the SES to benthic fisheries. We added around 37 second-, third-, and fourth-tier variables, mainly to represent the diversity of rules-in-use present in the management of benthic artisanal fisheries. The monitoring and sanctioning diversity was an important addition as new tiers for the governance system. Finally, we added third-tier variables in the Actors' domain. These variables were mainly third-tier aspects related to fishers' history of past experiences, leadership, importance of resources for livelihoods, and access to harvesting technology (Table 1).

\subsection{Two illustrative applications of the benthic fisheries SES framework}

We illustrate how an analyst can use the benthic SES framework depending on their interests by using Table 1 to select different components. The first application shows how factors influenced three Mexican fisheries' capability to avoid the tragedy of open access. Variables related to the Governance System, Resource System, and Actors explained self-organization capabilities among these fisheries. In the Chilean case, the Resource System and Resource Units remained constant over time and therefore did not need to be included in the analysis. Variables within the Governance System and Actors explain changes in self-organization capacity. In the following section, we provide a detailed description of each of the two studies in Chile and Mexico.

4.2.1. An example from three Mexican fisheries on the emergence of local organization capacity to control access

Like many other small-scale fisheries in Mexico, the Seri, Kino, and Peñasco fisheries, and the benthic sessile species that they target, are not actively regulated by government authorities. As a result, these fisheries enjoy significant levels of autonomy to determine their own operational access and harvesting rules (GS6.2) unless challenged. These fishers harvest sessile species of mollusks (mainly sea pen shells - Atrina spp., Pinna rugosa, but also rock scallops - Spondylus calcifer, and murex snails - Hexaples nigritus). In all cases, fishers use the same technology of exploitation common among small-scale divers in the region (A9.2): a rudimentary underwater breathing apparatus called hookah adapted to a small ( $\sim 8 \mathrm{~m})$ fiberglass outboard motorboat (Basurto, 2006).

The towns of Puerto Peñasco and Kino Bay were first established as sea bass totoaba (Totoaba macdonaldi) fishing camps during the 1930s (Bahre et al., 2000). The Seri - a nomadic group at the time had an active participation in the highly profitable Totoaba fishery in Kino, which in 1940 would eventually prompt the Seri to establish their own fishing camp and become a sedentary group (Smith, 1954). Since their establishment, Puerto Peñasco and Kino have attracted fishers from all over Mexico, lured to settle by the promise of local booming fisheries and coastal developmentrelated economic activities. Between 1945 and 1950, the population of Puerto Peñasco, Kino, and the Seri was around 2500 (Ives, 1989), 500 (Moreno et al., 2005a), and 300 (Felger and Moser, 1985), respectively. In the early 1970 s, fishing of benthic resources with hookah diving equipment began in these villages and all accounts indicate that before the 1980s, they were open-access regimes; that is, no rules had been established to control access to benthic resources (Basurto et al., 2012; Cudney-Bueno and Basurto, 2009).

As the population increased through natural growth and immigration (particularly Puerto Peñasco and Kino), so did the number of fishers and their likely competition for benthic resources. In 2005, the population of Puerto Peñasco, Kino, and the Seri stood at about 40,000, 5000, and 600 inhabitants, respectively (INEGI, 2005). The need to self-organize to control access and use to their benthic resources became evident. Kino's failed attempts to establish local vigilance and enforcement committees to control access to outsiders have been documented by Cinti et al. (2010). Those in control of the committees often found it in their own self-interest to allow outsiders to participate in their fisheries, undermining the committees' legitimacy within the fishing community (Cinti et al., 2010). It is widely perceived that pen shells are less abundant or overexploited in Kino Bay (Basurto et al., 2012; Moreno et al., 2005a). The available official statistical data reported by Moreno et al. (2005b) indicates that in 1992 the production in Kino Bay was almost 170 tones of sea pen shells (Atrina spp. and P. rugosa). Production has steadily dropped since 1992, and has averaged only 20 tons per year from 1997 to 2003. Local overexploitation of benthic resources has resulted, in turn, in an increased pressure by Kino fishers to attempt to gain access to still other abundant fishing grounds like those used by Peñasco or the Seri, their neighbors to the north.

Since the 1980s, the Seri have found incentives to face the costs of organizing to control access to their resources (Basurto et al., 2012). The number of incentives to organize relies on the Seri's collective knowledge accumulated over thousands of years of inhabiting the area and using benthic resources (A4) (Felger and Moser, 1985). The Seri have developed relevant notions of their resources' spatial boundaries and extent (RS3) and traditional knowledge about aspects of the biology and ecology that allow them to make rough predictions (RS6) about how their actions might affect the future state of their benthic resources (Basurto, 2008). Despite being relative newcomers to the region in comparison to the Seri, Kino Bay and Puerto Peñasco fishers seem to have also developed significant knowledge about the benthic resources they harvest (RS3, RS6) because such knowledge is likely germane to being a successful fisherman. 
Of all three fishing communities, only the Seri have formal territorial use of communal property rights (GS6.1.4.3) to their benthic sessile mollusk fishing areas. In 1975, the Mexican federal government granted the Seri with a fishing concession. Only those areas where the Seri most frequently fished, and therefore, developed access controls, became exclusive fishing zones for the Seri community (Basurto, 2005). Over time, these zones were widely recognized by other fishing communities - like Kino Bay or Puerto Peñasco - as of undisputed Seri ownership. All other coastal areas formally granted to the Seri, where they harvest mainly mobile species but not as frequently visited and used, or where they could not find cost-effective ways to develop access controls, have been claimed by other communities and are a constant source of contestation and conflict (Bourillón-Moreno, 2002).

The strong present and future economic (A8.1) and cultural dependence (A8.2) of the Seri on the resource and its territory has generated incentives to design communally accepted operational rules to access and use (GS6.2) their exclusive fishing zone. Further, they have been able to find ways to monitor each other's fishing activities and enforce (GS9) these rules in a cost-effective manner (Basurto, 2005). In contrast, Kino fishers are not as highly dependent on benthic fishing grounds for the maintenance of their livelihoods. Many Kino fishers also participate in other fisheries and are recent immigrants to the region. When confronted with the question of benthic resource scarcity, fishers often state they would harvest something else in the locality or pack up what they own and move elsewhere (Basurto, unpublished data).

It is also important to note that for hundreds of years, the Seri were subject to invasions by other dominant ethnic groups (i.e. Spaniards and, later, Mexican mestizos) in attempts to achieve religious and territorial conquest (Sheridan, 1999). Although always internally divided in family groups, the Seri have developed norms of trust and reciprocity (A6.1) toward defending themselves from what they might perceive as new domination attempts. Competition for fishing areas with neighboring communities is just another form in which the Seri perceive outsiders attempting to dominate them. This perception has effectively brought them together despite their internal differences. Indeed, long-term observers have described the Seri as "entrepreneurial" and "resourceful" in their adaptive capacity toward ever-changing external threats (A5) (Felger and Moser, 1985; Wilder, 2000). In contrast, Kino fishers have not been able to build strong trust and reciprocity relationships among fishing community members. Cinti et al. (2010) describe how heterogeneous preferences among different stakeholders in the fishing process create barriers for collective action.

Similar to Kino, Puerto Peñasco is a very dynamic and socially heterogeneous community. Here, a group of family-related fishers formed a fishing cooperative in the 1970s, Sociedad Cooperativa Buzos de Puerto Punta Peñasco, and in effect transferred much of their previously built trust and reciprocity into the fishing arena. For roughly the same amount of time as Kino and the Seri $(\sim 30$ years), Peñasco co-op divers have been commercially diving rocky reefs and adjacent coastal sandy areas, and are locally recognized as the established harvesters of benthic resources in Peñasco.

Peñasco divers' specialization on sessile benthic resources makes them very aware of the fact that they would be the first to suffer the consequences of overexploiting them. In 2000, they began to experiment with the rotation of benthic mollusk beds, in the hopes that this would enable them to avoid overexploitation scenarios. That same year, facing increased competition with fishers and other stakeholders using the same coastal resources, divers approached researchers and a non-governmental organization (NGO) for support to quantify changes in one of their most important fishing areas. The diving co-op received significant support and leadership (A5) from university researchers and funding organizations that enabled it to afford the costs of selforganizing into a common-property regime. They implemented a local network of marine reserves designed to protect and enhance stocks of the benthic resources on which the co-op depended to maintain their livelihood (A8.1).

Researchers and the NGOs trained divers on safe diving procedures, provided arenas for the discussion and exchange of ideas, and took on some of the financial, logistic, scientific, and implementation burdens related to the establishment of the network of marine reserves. This helped to build important linkages with environmental and local government fisheries management agencies and led to the informal recognition among local stakeholders that the fishing co-op had de facto property rights (GS6.1.4.3) over the benthic resources being protected at the reserves. In addition, local divers were fully engaged in biological monitoring (GS9.2) and scientific knowledge development (A7). Within the above setting, co-op divers were able to design and successfully establish monitoring and enforcement rules-in-use for the benthic resources held within the reserves. After two years of limiting fishing in these areas, biological monitoring confirmed minimal harvesting activity (Cudney-Bueno and Basurto, 2009). Further, the biological monitoring generated strong evidence for a sharp increase in the density of benthic resources inside the marine reserves, as compared to before their establishment. Early positive results allowed divers to link their monitoring and enforcement efforts with an increase in the stock of their benthic resource units (Cudney-Bueno and Basurto, 2009).

In sum, the Seri and Peñasco fishers developed positive incentives to change from an open access to a common property-rights regime. These two groups of fishers found that developing a new set of operational rules (GS6.2) to control access and use to their fishing grounds would bring them more benefits than the status quo of open access (GS6.1.1). Furthermore, in their ability to implement institutional change successfully, they also needed to be able to surpass the perceived costs of changing their rules (see Basurto and Ostrom, 2009 for the theoretical model underpinning these statements). As we described above, their ability to do so was likely a function of the combination of specific third-, fourth-, and fifth-tier variables related to the Actors (A), and their Governance System (GS), while these same variables were mostly absent in the Kino Bay case. More specifically, Table 2 shows that the Peñasco and the Seri fisheries had developed shared local knowledge/mental models of their resource, found or developed local leadership (A5) conducive to controlling access and use of their fishing areas, shared high levels of trust and reciprocity (A6.1), and were highly economically dependent on their benthic fisheries (A8.1). All these elements were absent or lacking in the Kino Bay case. Regarding their Governance System (GS), the Seri and Peñasco fishers had formal or informal property rights and had developed social monitoring mechanisms (GS9.1) and graduated sanctioning systems (GS10.1) to maintain their operational rules. In the Kino case, this system was mostly absent. In sum, the absence of these factors at Kino Bay likely elevated the costs of organizing to the extent that surpassed the likely expected benefits of organizing into a common-property regime. Thus, Kino fishers were not able to find enough incentives to move away from the open access status quo. As a consequence - just as Hardin had predicted for open-access fisheries - their benthic resources were eventually overharvested.

4.2.2. An over-time example from a Chilean bull-kelp fishery on the loss and recovery of local organization capacity

Through our case study from Chile, we illustrate how the SES framework can be used to study the unintended effects of particular policy interventions so that dangerous combinations 
Table 2

Comparison of key variables for three coastal fisheries in the Gulf of California.

\begin{tabular}{|c|c|c|c|c|}
\hline & Working definition & Kino & Peñasco & The Seri \\
\hline \multicolumn{2}{|l|}{ Successfully self-organized } & No & Yes & Yes \\
\hline \multicolumn{5}{|l|}{ Actors (A) } \\
\hline Number of actors (A1) & $\begin{array}{l}\text { Number of actors affecting decision-making processes } \\
\text { related to harvesting in the fishery }\end{array}$ & Rapid growth & Rapid growth & Slow growth \\
\hline Local leadership (A5) & $\begin{array}{l}\text { Actors who have skills useful to organize collective action } \\
\text { and are followed by their peers }\end{array}$ & Absent & Present & Present \\
\hline Trust and reciprocity (A6.1) & $\begin{array}{l}\text { Trust is a measure of the extent to which members of a } \\
\text { community feel confident that other members will live up } \\
\text { to their agreements even if doing so may not be in their } \\
\text { immediate interest. Reciprocity is a symmetrical response } \\
\text { to a previous cooperative or defective action by a member } \\
\text { of the community }\end{array}$ & Lacking & High levels & High levels \\
\hline $\begin{array}{l}\text { Shared local knowledge/mental } \\
\text { models (A7) }\end{array}$ & $\begin{array}{l}\text { Degree to which stakeholders understand and make sense } \\
\text { of the characteristics and/or dynamics of the SES }\end{array}$ & Low & High & High \\
\hline Economic dependence (A8.1) & $\begin{array}{l}\text { The resource constitutes a source of monetary income and } \\
\text { plays a major role in fishers' ability to sustain their } \\
\text { livelihoods }\end{array}$ & Low & High & High \\
\hline Cultural dependence (A8.2) & $\begin{array}{l}\text { The resource constitutes a source of cultural values, } \\
\text { practices, and services, and plays a major role in the fishers' } \\
\text { ability to sustain their livelihoods }\end{array}$ & Low & Low & High \\
\hline \multicolumn{5}{|l|}{ Governance Systems (GS) } \\
\hline $\begin{array}{l}\text { Formal or informal territorial use } \\
\text { communal property rights (GS6.1.4.3) }\end{array}$ & $\begin{array}{l}\text { Agreed-upon areas for which permanent or limited } \\
\text { property rights are granted to all members of a formal } \\
\text { organization created for purposes other than fishing }\end{array}$ & Absent & Present & Present \\
\hline Operational rules (GS6.2) & $\begin{array}{l}\text { Implementation of practical decisions by individuals } \\
\text { authorized (or allowed) to take these actions }\end{array}$ & Present & Present & Present \\
\hline Social monitoring (GS9.1) & $\begin{array}{l}\text { Local actors, or outsiders legitimized by them, observe that } \\
\text { other actors comply with agreed-upon behavior in the use } \\
\text { of the resource system and units }\end{array}$ & Mostly absent & Mostly present & Mostly present \\
\hline Biological monitoring (GS9.2) & $\begin{array}{l}\text { Local actors, or outsiders legitimized by them, observe the } \\
\text { condition of the resource system and units }\end{array}$ & Absent & Present & Mostly present \\
\hline Graduated sanctions (GS10.1) & $\begin{array}{l}\text { Actors who violate operational rules are given a sanction } \\
\text { coherent with its seriousness and the times the offense has } \\
\text { been committed }\end{array}$ & Mostly absent & Mostly present & Mostly present \\
\hline \multicolumn{5}{|l|}{ Resource Systems (RS) } \\
\hline Resource size (RS3) & $\begin{array}{l}\text { Absolute or relative descriptions of the spatial extent of a } \\
\text { resource system }\end{array}$ & Large & Small & Small \\
\hline Predictability (RS6) & $\begin{array}{l}\text { Degree to which actors are able to forecast or identify } \\
\text { patterns in environmentally driven variability on } \\
\text { recruitment }\end{array}$ & $\begin{array}{l}\text { Least } \\
\text { predictable }\end{array}$ & $\begin{array}{l}\text { Moderately } \\
\text { predictable }\end{array}$ & $\begin{array}{l}\text { Moderately } \\
\text { predictable }\end{array}$ \\
\hline
\end{tabular}

of policies devised at diverse tiers or attributable to particular aspects of a Resource System (RS) and Resource Units (RU) can be avoided in the future. These lessons are of particular importance to avoid the implementation of panacea-type policy interventions by governments and donor agencies around the world with little regard for existing management arrangements. Common-pool resource scholars identified this problem more than twenty years ago (NRC, 2002). The case study from Puertecillo, Chile, in which a territorial use rights fisheries (TURFs) policy was implemented over an existing traditional management system, constitutes a strong case in point (Gelcich et al., 2006). We conceptualize this study as a comparison of the same fishing community in three different consecutive points in time: (1) the ecosystem was exclusively managed through a traditional management system developed by the local fishers; (2) the system was governed exclusively by an official, biologically driven, national-level TURFs policy; and (3) the system was governed through a new regime that integrated the previous governance approaches.

Puertecillo ( $34^{\circ} 17^{\prime} \mathrm{S} ; 71^{\circ} 58^{\prime} \mathrm{W}$ ) is a rural area located in region VI of Chile. There are 49 households in Puertecillo and a total population of 195 (SECPLAC, 2005). Puertecillo fishers' income is largely dependent on the sale of the brown bull-kelp (Durvillaea antarctica), which is dried for human consumption. Fishers from Puertecillo have been harvesting bull-kelp for generations (A3.2). Bull-kelp is harvested and sold during the summer months (November-March), and its income is used to buy basic food supplies for the winter (Gelcich et al., 2006). Fishers in Puertecillo historically enjoyed a significant level of autonomy to determine their own operational access and harvesting rules (GS6.2), which led to the creation of a traditional management system held in place for more than 100 years until challenged by a national TURFs policy adopted in Puertecillo in 2003. During this TURFs-based management period, local management practices were eroded and the sustainability of the whole social-ecological system threatened for around four years. Following the implementation of the TURFs period, a process of cross-scale institutional learning provided the foundation for modifying rules. By this process, we mean a multiscale process by which collaboration takes place between parties within a specific network or community of practice. As such, it is a system-wide learning process between and across organizations and agencies. The process of cross-scale institutional learning took nearly a decade to develop as an alternative management pathway. The process eventually allowed Puertecillo fishers and the local fisheries agencies to rise to the resource management challenge of adapting their traditional practices to fit contemporary circumstances. We highlight the changes and key aspects determining fishers' ability to engage in collective learning for successful self-organization (or not) during each time period by using the SES framework (Table 3).

4.2.2.1. Time period 1: The informal traditional governance regi$m e$. The traditional governance regime system in Puertecillo gives 
Table 3

Comparison of key SES variables for three distinct governance time periods in Puertecillo, Chile.

\begin{tabular}{|c|c|c|c|c|}
\hline Variable (code) & Working definition & $\begin{array}{l}\text { Puertecillo } \\
\text { Time } 1\end{array}$ & $\begin{array}{l}\text { Puertecillo } \\
\text { Time } 2\end{array}$ & $\begin{array}{l}\text { Puertecillo } \\
\text { Time } 3\end{array}$ \\
\hline Successfully self-organized & & Yes & No & Yes \\
\hline \multicolumn{5}{|l|}{ Actors (A) } \\
\hline Number of actors (A1) & $\begin{array}{l}\text { Number of actors affecting decision-making processes } \\
\text { related to harvesting in the fishery }\end{array}$ & Stable & Stable & Stable \\
\hline Local leadership (A5) & $\begin{array}{l}\text { Actors who have skills useful to organize collective } \\
\text { action and are followed by their peers }\end{array}$ & Present & Present & Present \\
\hline Trust and reciprocity (A6.1) & $\begin{array}{l}\text { Trust is a measure of the extent to which members of a } \\
\text { community feel confident that other members will live } \\
\text { up to their agreements even if doing so may not be in } \\
\text { their immediate interest. Reciprocity is a symmetrical } \\
\text { response to a previous cooperative or defective action } \\
\text { by a member of the community }\end{array}$ & High levels & Low levels & Moderate levels \\
\hline Shared local knowledge/mental models (A7) & $\begin{array}{l}\text { Degree to which stakeholders understand and make } \\
\text { sense of the characteristics and/or dynamics of the SES }\end{array}$ & High levels & Low levels & High levels \\
\hline Economic dependence (A8.1) & $\begin{array}{l}\text { The resource constitutes a source of monetary income } \\
\text { and plays a major role in fishers' ability to sustain their } \\
\text { livelihoods }\end{array}$ & High & High & High \\
\hline Cultural dependence (A8.2) & $\begin{array}{l}\text { The resource constitutes a source of cultural values, } \\
\text { practices, and services, and plays a major role in the } \\
\text { fishers' ability to sustain their livelihoods }\end{array}$ & High & High & High \\
\hline \multicolumn{5}{|l|}{ Governance Systems (GS) } \\
\hline Vertical governance network structure (GS8.2) & $\begin{array}{l}\text { Link actors with other organizations or the state across } \\
\text { levels }\end{array}$ & Low & High & High \\
\hline Horizontal governance network structure (GS8.1) & $\begin{array}{l}\text { Link actors with each other to act collectively for a } \\
\text { common purpose }\end{array}$ & High & Low & High \\
\hline Formal recognition property/use rights (GS6.1) & $\begin{array}{l}\text { Particular types of rules determining which actors have } \\
\text { been authorized to carry out which actions with respect } \\
\text { to a specified good or service }\end{array}$ & Absent & Present & Present \\
\hline $\begin{array}{l}\text { Presence of traditional use privileges: } \\
\text { individually owned fishing spots (GS6.1.4.2) }\end{array}$ & $\begin{array}{l}\text { Human-constructed or agreed-upon areas for which } \\
\text { permanent or limited property rights are granted to } \\
\text { individual fishers }\end{array}$ & Present & Absent & Present \\
\hline Operational rules (GS6.2) & $\begin{array}{l}\text { Implementation of practical decisions by individuals } \\
\text { authorized (or allowed) to take these actions }\end{array}$ & Present & Present & Present \\
\hline Biological monitoring (GS9.2) & $\begin{array}{l}\text { Local actors, or outsiders legitimized by them, observe } \\
\text { the condition of the resource system and units }\end{array}$ & Mostly present & Mostly present & Mostly present \\
\hline Graduated sanctions (GS10.1) & $\begin{array}{l}\text { Actors who violate operational rules are given a } \\
\text { sanction coherent with its seriousness and the times } \\
\text { the offense has been committed }\end{array}$ & Mostly present & Mostly present & Mostly present \\
\hline
\end{tabular}

access rights to eligible members of the community to undertake harvesting activities in designated grounds (known locally as "parcela"). In essence, use privileges are granted to individually owned harvesting spots through a lottery system (GS6.1.4.2). These use privileges are customary access rights legitimized by social norms and codes of behavior that have been in place for at least 100 years. In addition, through the traditional management practices, fishers have gained and shared effective knowledge about the resource system and resource units they are using (A7.1), developing norms of trust and reciprocity with those with whom they have close interactions (A6.1). For instance, the community has a process called "mingaco" in which the owner of a parcela gives food and drink in return for a day's assistance in harvesting. Through a different set of rules, the fisher community allows widows, who do not have the physical capability to extract algae, to collect what is washed ashore naturally by waves. The washedashore algae would normally be collected by parcela owners; however, this local rule allows widows to continue harvesting bullkelp when they reach an age where they cannot afford assistance for extraction (Gelcich et al., 2006).

Parcelas are granted to each individual fisher through a lottery system that takes place once a year. Once a parcela is granted, the fisher has the right to decide how the parcela is to be managed for a one-year period. Nevertheless, bull-kelp extraction is not permitted between April 1 and September 30. This is a voluntary measure related to the biology of the algae that emerged through local knowledge of the system (A7). It is well fitted to scientific knowledge (Santelices et al., 1980) that suggests that the period outside the closed season is when the algae grows faster, and therefore one or two harvests can be attained. This harvesting and governance strategy is only possible because the bull-kelp (RU) has a fast yearly growth rate (RU2: Castilla and Bustamante, 1989) and is a small distance disperser (RU3.2: Castilla et al., 2007); thus, the conservation of adult populations has important seeding effects for nearby areas, and seeds do not migrate to distant harbors.

Under the traditional system in Puertecillo, the fishers had considerable autonomy to develop and experiment with their own de facto operational rules related to who fishes, when the fishing season opens or closes, size limits, access areas, and other local rules. However, the lack of legal recognition of the system made it extremely fragile to poaching from outsiders coming from other towns (Gelcich et al., 2006, 2009).

4.2.2.2. Time period 2: TURFs policy enacted. In Puertecillo, conditions related to autonomy in making rules were already present when the national-level TURFs policy began operating in 2003. Under the TURFs policy, the Chilean Undersecretary of Fisheries is authorized to assign formal user rights to artisanal fisher unions in defined geographical coastal areas (San Martin et al., 2010). In order to be granted a TURF, Chilean artisanal fisher organizations have to comply with a series of regulations (details in Gelcich et al., 2007) that include establishing a baseline study and a five-year management plan, for which they have to contract technical assistance from specialized biological consultants. Although the policy has been quite successful in regions of Chile where no 
traditional management practices existed, unfortunately, in Puertecillo, one year after the formal TURF had been granted and implemented, signs of bulk-kelp overexploitation and associated fishers' social unrest began to become evident (Gelcich et al., 2006). In essence, once the TURFs policy was implemented, fishers no longer depended on shared norms of trust and reciprocity (A6.1), or practices associated with the generation of local knowledge for harvesting strategies (A7). A few members of the community lost incentives to maintain operational community rules and rapidly exploited the stocks before enforcement officials (GS5.1.1) took much note of what was happening (Gelcich et al., 2006).

The TURFs policy eroded local institutions mainly affecting Actors (A) and the Governance System (GS). For instance, TURFs did provide legal recognition of a portion of the coast to the fishers of Puertecillo (GS6.1.4.3), but had negative effects mainly over congruence of rules to local conditions and over levels of participation on collectivechoice arrangements, such as how to enforce and harvest. This strongly affected the equity and social cohesion of the system, particularly as it related to trust and reciprocity among fishers (A6.1). The harvesting derogations for widows were banned, and "mingacos" were replaced by the legal requirement for all fishers to participate in a collective harvest (Gelcich et al., 2006).

In addition, the mechanism to sell resources changed from individual bargaining with middlemen to collective bargaining. This changed the power relations in the union, as some members have the power to make crucial bargaining decisions, creating new vertical social relations among a few fishers, consultants, and middlemen (GS8.2). These vertical relationships were potentially positive to access new markets and gain support for enforcement. However, they were mainly used to serve individual interests, making the fisher organization become susceptible to the influence of key and powerful leaders (A5) and affecting trust, bonding relations (A6.1), and knowledge sharing about their SES within the union (A7.1). Indeed, duties associated with obeying TURFs rules discouraged fishers from maintaining an adaptive capacity and effectively using their knowledge for the management of coastal resources (A7.1). The TURFs policy implicitly established that the fisheries undersecretary set and control the management objectives (GS5.1.1). It also determined that research-based biological knowledge is the basic knowledge to include in the TURFs monitoring and evaluation (GS9). Thus, monitoring of the system was still in place, but it changed from a local continually adaptive monitoring system to the use of a formal biological indicator (GS9.2). The irony is that the TURFs policy, which was quite successful in other areas of Chile (Gelcich et al., 2010), was not devised to fit the social-ecological system of Puertecillo, generating more costs than benefits for the ecosystem and the fishers who depended on it.

4.2.2.3. Time period 3: Merging of the traditional and formal TURFs governance regimes. After a few years governing bull-kelp exclusively under the national TURFs regime, fishers evidenced that the social-ecological system was reaching a biological and social crisis. A process that included cross-scale institutional learning and the consolidation of horizontal relations between fishers and local fisheries agencies - which had been latent (GS8.1) - provided the foundation for an attempt to modify operational rules once again. This process has taken nearly a decade to develop a new management pathway, but is now allowing Puertecillo fishers and the local fisheries agencies to rise to the challenge of adapting traditional practices and nationally developed TURF rules to fit local circumstances. This new resultant system is still informal, but the authorities and fishers are determined to make it work (Gelcich, unpublished data).

At Puertecillo, mechanisms not directly related to fishing helped to maintain social capital (A6) within the community and counterbalance the effects of fragmentation within the fisher union. Social capital provided a social cohesion that remained latent until the TURFs system became untenable, calling for new collective-action strategies. This latent social capital was maintained through other community-level interactions and activities that had no relation with fishing, such as the local assembly, a commission created to obtain support to build access roads to Puertecillo, and the rural water committee (Gelcich, unpublished data). All of these relations are embedded in the day-to-day interactions of Puertecillo's small and active community (A1). In addition, the presence of keystone linking agents between the local fisheries service and the fisher union was important in navigating the shift from TURFs to a new set of regulations. These agents included a well-respected fisher union leader (A5) and the local fisheries service officials who began trusting fishers.

The resulting governance regime in Puertecillo is still changing. It currently includes recognition of territorial use rights (GS6.1.4.3) and the reestablishment of individually owned parcelas under lottery assignation (GS6.1.4.2), the "mingaco" and the harvesting alternatives for widows. All of these rules are helping to rebuild trust and reciprocity (A6.1) and shared local knowledge of the system (A7). Resource monitoring systems also include rules by which local knowledge can be integrated with the formal monitoring (GS9.2) in a process that is developing both bonding and linking relationships for the first time in the history of Puertecillo (GS8.1 and GS8.2).

An examination of the SES of parcelas through time has enabled us to identify the specific variables that might be hampering or facilitating successful collective action for resource use sustainability in Puertecillo. It is interesting to note how the characteristics and dynamics of the Governance System (GS) and Actors (A) have been instrumental in regenerating the parcela system for it to operate in a new, complementary way to the official TURFs regime. The importance of trust and reciprocity (A6.1), positive leadership (A5), shared local knowledge (A7), and a combination of both horizontal and vertical governance network structures (GS8.1 and GS8.2) all appear to have an important contribution in establishing more desirable collective-action arrangements for the management of common-pool resources (Table 3). Using the SES framework by including new tiers within these variables can shed important insights on its application for policy analysis of small-scale fisheries in the context of existing traditional management practices.

\section{Discussion}

Most understanding of key factors affecting governance of benthic small-scale fisheries has been derived from case studies (but see Cinner et al., 2012; Gutiérrez et al., 2011 for large-n approaches). Here we have used this existing scientific literature to adapt Ostrom's SES framework as a way to build a classification system for knowledge accumulation or an ontology of benthic fishing SESs. In the process of adapting the general SES framework, it became clear that new tiers were necessary to represent the particularities of benthic small-scale fisheries. Although other studies are adapting the framework to irrigation (Ostrom and Cox, 2010; Villamayor-Tomas, 2012) and federal river systems (Garrick et al., 2013), none of them have yet explored what the addition of fourth- and fifth-tier variables might look like. Our approach was especially important to visualize and represent the heterogeneity in governance and rules-in-use within the benthic fisheries SES. Depending on the purposes of analysis, a scholar could take into account variables/processes at different levels of aggregation or develop further tiers according to the needs generated in specific comparative studies. The cases on self-governance presented from Mexico and Chile illustrate how in-depth studies can be organized 
using the SES framework as a classificatory system of benthic fisheries. Here we discuss the potential of this approach to enable the documentation of combinations of conditions, at specific levels of aggregation, associated with certain types of outcomes of interest.

Organizing the Mexico study using the benthic SES framework illustrates what combinations of conditions allowed Puerto Peñasco and the Seri to self-organize to control access to their fisheries, while Kino failed to move away from an open-access regime (Table 2). Note that Peñasco and the Seri communities arrived at local self-organization through two different combinations of conditions or paths, illustrating the importance that conjunctural or multiple causation can play in understanding interactions and outcomes in complex SESs. The importance of looking at combinations of social-ecological variables/processes to understand interactions is similarly illustrated in the Chile study, although it is structured very differently by comparing the fishing community of Puertecillo in three different time periods (Table 3 ). The framework allowed the identification of the different conditions that affected fishers' ability to self-organize in different time periods. For instance, using the framework allowed fairly easily the summarization of the unintended consequences of a national-level designed TURFs governance regime, which resulted in the loss of Puertecillo's self-organization capacity in time-two. In time-three, however, Puertecillo recovered its self-organization capacity through a process of institutional learning, among other factors. In summary, the Mexico and Chile studies show how versatile a benthic small-scale fisheries ontology can be to focus on different case studies or different time periods. In addition, it shows how different fisheries (i.e. the Seri, Peñasco, Puertecillo) arrived at local or self-governance through different combinations of conditions or pathways.

For analysts interested in exploring which social-ecological factors were associated with self-governance among the Seri, Peñasco, and Puertecillo fisheries, we saw that: All cases had presence of local leadership (A5), moderate to high levels of trust and reciprocity (A6.1), high levels of shared local knowledge (A7), high economic or cultural dependence on the resource to sustain their livelihoods (A8.1 or A8.2), presence of social or biological monitoring (GS9.1 or GS9.2), and presence of formal or informal property rights (GS6.1) expressed in diverse forms of territorial use privileges (GS6.1.4). In this example, factors A5, and A7 are located at the second tier, while A6.1, A8.1, A8.2, GS9.1, and GS9.2 are third-tier factors, and GS6.1.4 are fourth-tier factors. The ChileMexico comparison relied on variables aggregated at different tiers to find similarities between the cases. Another study, however, could have focused only on examining the fifth-tier variables related to the different forms of territorial use privileges (GS6.1.4) that contributed to successful self-organization in Mexico and Chile. In Chile, territorial use rights were organized through individually owned fishing spots (GS6.1.4.2), while in Mexico the Seri did so through territorial use communal rights (GS6.1.4.3). Learning how these differences emerged at each place could be the entire focus of an in-depth case study. These two examples, while focused on different tiers, are operating within the same framework and thus can make it easier to link studies favoring different levels of generality and specificity into more coherent bodies of knowledge about a subject of interest.

When dealing with complex systems, it might not be possible to determine the role of a particular variable in generating the outcome observed. But it seems possible to identify which combination of variables can be associated with certain outcomes. Thus, tracking such configurations of conditions and their associated outcomes might constitute a first step toward developing systematic approaches to the study of complex systems governance (Cox, 2011).
Being able to recognize how the same phenomena can be characterized by multiple causality has policy implications because it increases the range of options available toward developing policy prescriptions that avoid panaceas.

Having described some of the potential ways the SES framework can be used in small-scale benthic fisheries, we would like to point out some remaining weaknesses that need to be addressed for its continued development. For instance, establishing second- and third-tier attributes for some conditions, such as learning and leadership, is not straightforward. This was particularly relevant from the Chilean case study, where learning (i.e. individual, social, and institutional) is hypothesized to have played an important role in the emergence of self-organization through time. McGinnis and Ostrom (2013) also point out that the framework does not allow an easy way of incorporating learning as a second-tier attribute. In the Puertecillo example, much of the learning processes from the traditional management system were latent for nearly five years due to the complex process of adaptation to new circumstances. It is a challenge to determine where these important learning processes should be located within the SES framework. Another challenge relates to conceptualizing the role of leaders. Although present in the framework, it needs to be further developed. The experience in Chile showed that leaders can play multiple roles, and that they must understand the ways in which others are viewing their lives. Leaders are also expected to see possibilities and to discern and develop paths of action that might otherwise go unexplored (Gelcich et al., 2010). In addition, leaders are expected to exercise high-order interpersonal communication capacities (Graen and Uhl-Bien, 1995). However, all of these characteristics can be used to enhance or weaken collective action. In this sense, the role of power, and how discourses are constructed by leaders regarding benthic fisheries SESs (Gelcich et al., 2005), is something that we feel needs to be strongly developed within third- or fourth-tier variables in the future.

\section{Conclusion}

In closing, we note some common misunderstandings and remaining challenges to the implementation of the approach presented here.

First, it is often misunderstood that all variables in the SES framework are needed for one particular analysis. It is unlikely that anyone can keep track of all of the variables listed in Table 1. One can, however, hold some variables constant while focusing on some others, as we did in our studies in Mexico and Chile. Second, we view the analysis we conducted as broadly applicable to the analysis of general problems involving human-environmental interactions outside of the purview of the self-organization, common-pool resources literature, and its academic tradition. Researchers working under other traditions can also find this classificatory system useful in organizing and exploring other types of questions or issues related to social-ecological systems.

Third, in using the SES framework, we cannot overemphasize that it is a starting, not an ending, point for inquiry on governance of SESs. Using it as a checklist tablet is unlikely to be very productive. Careful assessment of the meaning of the variables depicted, and understanding of the local context to which the analysis applies, is irreplaceable. The use of a variety of tools in empirical field research, such as grounded theory, among others, will be key to avoid blind spots and make progress in the development of a tiered ontology. As we gain a better understanding of how concepts are embedded and related to each other, it might be easier to elucidate the third-, fourth-, and fifth-tiers of the framework.

Finally, we view classificatory frameworks as basic heuristic tools used by humans since time immemorial (e.g. alphabets or 
ethno-classifications) to organize information about a particular phenomena or system of interest (Madin et al., 2008; Salafsky et al., 2008). They are analytical tools to work through complexity, not a statement about the world we live in, which is necessarily much more complex (Basurto and Nenadovic, 2012). Classificatory frameworks, however, can also slow down knowledge accumulation and be misused as checklists for problem analysis, and because they necessarily embed a certain worldview and the normative values held within such worldview, they can create blind spots toward other potential relevant processes and variables, or different worldviews. These issues are often less a function of any particular framework, and more an indication of poor scholarship practice and understanding of the complexity entailed by the social processes described in the framework. In this paper, we take the position that exploration, debate, and design of a classificatory framework like the SES framework constitutes an important enterprise because it offers the promise to make headway toward building diagnostic theories for policy analysis (McGinnis and Ostrom, 2013; Ostrom, 2007, 2009; Young, 2002; Young et al., 2008).

Diagnostic theories for policy analysis are a promising approach to bridge the divide between, on the one hand, policy lessons derived from generalizable models that have been applied across the board as "panaceas" (e.g. the tragedy of the commons) and, on the other hand, from policy analysis that presumes that all individual settings are so different from one another that all we can do is describe the intricate detail of particular settings (Wagner and Talakai, 2007). We welcome feedback from other scholars working with benthic fisheries on future modifications tailored to improve the SES framework potential for the accumulation of knowledge related to benthic small-scale fisheries.

\section{Acknowledgments}

We thank the following colleagues for their comments and assistance on earlier drafts: Nicole Carlozo, Larry Crowder, Graham Epstein, Ursula Kreitmair, and Doug Perron. Elinor Ostrom acknowledges financial support from FORMAS through the program Human Cooperation to Manage Natural Resources (COMMONS) and from the US National Science Foundation. Stefan Gelcich thanks ICM of the Ministerio de Economía, Fomento y Turismo and Fondecyt 1120103. Xavier Basurto thanks the support of The Christensen Fund and Duke University. We were fortunate to have the excellent editorial assistance of Patty Lezotte and Saiontoni Sarkar.

\section{Appendix A}

A summary of the modifications made to the SES framework (Ostrom, 2009), to tailor it for small-scale benthic resource fisheries, is organized by first-tier variables:

\section{Modifications to Resource Systems (RS):}

- Eliminated "Human-constructed facilities" (RS4) because it is now captured by "Storage in a human-designed facility" (RS7.2).

- Added one second-tier variable: "Connectivity" (RS8) (Table 1).

- Added five third-tier variables: RS1.1, RS4.1, RS4.2, RS7.1, RS7.2 (Table 1).

\section{Modifications to Resource Units (RU):}

- Added four third-tier variables: RU3.1, RU3.2, RU6.1, RU6.2 (Table 1).

\section{Modifications to Governance Systems (GS):}

- Following updates suggested by McGinnis and Ostrom (2013), five new second-tier variables were added: Policy area (GS1), Geographic range (GS2), Population (GS3), Regime type (GS4), Norms and strategies (GS7).

- Following updates suggested by McGinnis and Ostrom (2013), three original second-tier variables were moved to a third-tier: Operational rules (GS6.2), Collective-choice rules (GS6.3), Constitutional rules (GS6.4). All of them are now under "Rules-in-use" (GS6). Substitutes for original second-tier variables (moved to third-tiers) are: "Organizations" (GS5) substituted "Non-government organizations," which became a third-tier variable (GS5.2). "Rules-in-use" (GS6) substituted "Property-rights systems," which became a third-tier variable (GS6.1).

- Added fifteen third-tier variables (some of which are mentioned above): GS1.1, GS4.1, GS4.2, GS5.1, GS5.2, GS6.1, GS6.2, GS6.3, GS6.4, GS8.1, GS8.2, GS9.1, GS9.2, GS10.1, GS10.2.

- Added eleven fourth-tier variables: GS1.1.1, GS5.1.1, GS5.1.2, GS5.1.3, GS5.2.1, GS5.2.2, GS5.2.3, GS6.1.1, GS6.1.2, GS6.1.3, GS6.1.4

- Added three fifth-tier variables: GS6.1.4.1, GS6.1.4.2, GS6.1.4.3. Modifications to Actors $(A)$ :

- Renamed first-tier variables from Users (U) to Actors (A).

- Renamed second-tier variables from "History of use" to "History or past experiences," from "Norms/social capital" to "social capital," from "Dependence on resource" to "Importance of resource," and from "Technology used" to "Technologies available."

- Added eight third-tier variables: A3.1, A3.2, A6.1, A7.1, A8.1, A8.2, A9.1, A9.2.

See Tables A.1-A.4.

Table A.1

Resource Systems (RS). ${ }^{a}$

\begin{tabular}{|c|c|c|}
\hline Attribute & Working definition & Reference \\
\hline RS1 - Sector & $\begin{array}{l}\text { Characteristic(s) of a resource system that distinguishes it from other resource } \\
\text { systems }\end{array}$ & $\begin{array}{l}\text { Ostrom }(2007)^{\mathrm{b}} \\
\text { Cox et al. }(2010)^{\mathrm{b}}\end{array}$ \\
\hline RS1.1 Marine benthos & $\begin{array}{l}\text { Sessile or mobile shellfish or mollusks harvested by humans through diving or } \\
\text { gathering in shallow areas }\end{array}$ & Castilla and Jerez (1986) \\
\hline RS2 - Clarity of system boundaries & $\begin{array}{l}\text { Biophysical characteristics that make feasible for actors to determine where the } \\
\text { resource system starts or ends }\end{array}$ & Foale (1998) \\
\hline RS3 - Size of resource system & Absolute or relative descriptions of the spatial extent of a resource system & $\begin{array}{l}\text { Castilla et al. (1998) } \\
\text { Daw (2008) }\end{array}$ \\
\hline RS3.1 Carrying capacity & $\begin{array}{l}\text { The maximum number of resource units that the biophysical setting can sustain } \\
\text { indefinitely }\end{array}$ & Cabrera and Defeo (2001) \\
\hline RS4 - Productivity of system & $\begin{array}{l}\text { Rate of generation of units of biomass determined by production-consumption } \\
\text { rates per unit of time, surface, or volume }\end{array}$ & Moses et al. (2002) b \\
\hline
\end{tabular}


Table A.1 (Continued)

\begin{tabular}{|c|c|c|}
\hline Attribute & Working definition & Reference \\
\hline RS4.1 Stock status & $\begin{array}{l}\text { Rate of generation of units of biomass as determined by production in a given } \\
\text { year }\end{array}$ & $\begin{array}{l}\text { Froese and Kesner-Reyes (2002) } \\
\text { Diele et al. (2005) }\end{array}$ \\
\hline RS4.2 Biophysical factors & $\begin{array}{l}\text { Upwelling, biogeographic or geomorphological factors affecting the generation } \\
\text { of units of biomass }\end{array}$ & Johnson et al. (2012) \\
\hline RS5 - Equilibrium properties & $\begin{array}{l}\text { Characterization of the type of attractor of a resource system along a range from } \\
\text { one to multiple (chaotic) attractors }\end{array}$ & $\begin{array}{l}\text { Holling and Meffe (1996) } \\
\text { Scheffer et al. }(2003)^{\mathrm{b}}\end{array}$ \\
\hline RS6 - Predictability of system dynamics & $\begin{array}{l}\text { Degree to which actors are able to forecast or identify patterns in } \\
\text { environmentally driven variability on recruitment }\end{array}$ & $\begin{array}{l}\text { Dennis et al. (1992) } \\
\text { Defeo and Castilla (1998) } \\
\text { Foale (1998) }\end{array}$ \\
\hline RS7 - Storage characteristics & Degree to which the resource units can be held captive until harvested & $\mathrm{N} / \mathrm{A}$ \\
\hline RS7.1 Storage in their natural habitat & $\begin{array}{l}\text { Degree to which actors can leave resource units in their natural habitat, } \\
\text { assuring a later harvest }\end{array}$ & $\begin{array}{l}\text { Gelcich et al. (2007) } \\
\text { Cudney-Bueno and Basurto (2009) }\end{array}$ \\
\hline RS7.2 Storage in a human-designed facility & $\begin{array}{l}\text { Degree to which actors can store (e.g. artificial enclosure in land or cold storage) } \\
\text { resource units outside of their natural habitat for later harvesting }\end{array}$ & $\mathrm{N} / \mathrm{A}$ \\
\hline RS8 - Connectivity & Gene flow between different populations of resource units & Seijo (2007) \\
\hline RS9 - Location & Spatial and temporal extent where resource units are found by actors & Urban (1998) \\
\hline
\end{tabular}

a Defined as the biophysical system from which resource units are extracted and through which natural dynamic processes regenerate the levels of the focal resource.

b Citation is not a benthic fisheries-specific paper but generally applicable and relevant to illustrate the concept and definition.

Table A.2

Resource Units (RU). ${ }^{\mathrm{a}}$

\begin{tabular}{|c|c|c|}
\hline Attribute & Working definition & Reference \\
\hline RU1 - Resource unit mobility & $\begin{array}{l}\text { Sessile or slow moving for all or parts of benthic resources' life cycle when } \\
\text { interactions with fishers can take place }\end{array}$ & Johnson et al. (2012) \\
\hline \multirow[t]{5}{*}{ RU2 - Growth or replacement rate } & \multirow{5}{*}{$\begin{array}{l}\text { Absolute or relative descriptions of changes in quantities }(x) \text { of resource units } \\
\text { over time }(t)\end{array}$} & Dennis et al. (1992) \\
\hline & & Foale (1998) \\
\hline & & Cortez et al. (1999) \\
\hline & & Dietz et al. (2002) ${ }^{b}$ \\
\hline & & Metaxatos (2004) \\
\hline RU3 - Interaction among resource units & $\begin{array}{l}\text { Interactions among resource units during different life stages affecting the } \\
\text { future structure of the population }\end{array}$ & Guzmán and Tewfik (2004) \\
\hline RU3.1 Reproduction & Chemical or biophysical signals cue resource units for gamete release & Guillou and Michel (1993) \\
\hline RU3.2 Settlement & $\begin{array}{l}\text { Chemical or biophysical signals cue larvae to move out of the water column and } \\
\text { into the benthos }\end{array}$ & Manriquez and Castilla (2007) \\
\hline RU4 - Economic value & $\begin{array}{l}\text { Value of resource units in relation to the portfolio of resources available to } \\
\text { actors }\end{array}$ & Gelcich et al. (2009) \\
\hline RU5 - Number of units & Number of resource units harvested or that could be potentially harvested & Dennis et al. (1992) \\
\hline RU6 - Distinctive characteristics & $\begin{array}{l}\text { Markings and/or behavioral patterns that can be identified in resource units and } \\
\text { affect actors' behavior toward them }\end{array}$ & Acheson and Wilson (1996) ${ }^{\mathrm{b}}$ \\
\hline RU6.1 Hatchery & $\begin{array}{l}\text { Actors can identify markings linking resource units to particular production } \\
\text { areas }\end{array}$ & $\mathrm{N} / \mathrm{A}$ \\
\hline RU6.2 Wild & Actors can identify markings linking resource units to their wild origin & $\mathrm{N} / \mathrm{A}$ \\
\hline RU7 - Spatial and temporal distribution & $\begin{array}{l}\text { Allocation patterns of resource units across a geographic area in a particular } \\
\text { time period }\end{array}$ & Cudney-Bueno and Basurto (2009) \\
\hline RU7.1 Patchy & Non-homogeneous spatial and temporal distribution of the resource units & Prescott and Cudney-Bueno (2008) \\
\hline RU7.2 Random & Homogeneous spatial and temporal distribution of the resource units & Morsan (2007) \\
\hline
\end{tabular}

a Defined as the characteristics of the units extracted from a resource system that can then be consumed or used as an input in production or exchanged for other goods or services.

b Citation is not a benthic fisheries-specific paper but generally applicable and relevant to illustrate the concept and definition.

Table A.3

Governance Systems (GS). ${ }^{a}$

\begin{tabular}{|c|c|c|}
\hline Attribute & Working definition & Reference \\
\hline GS1 - Policy area & Rule systems tailored for a particular area of knowledge, geography, or time & $\begin{array}{l}\text { Castilla and Fernandez (1998) } \\
\text { McGinnis and Ostrom (2013) }\end{array}$ \\
\hline GS1.1 Environment & $\begin{array}{l}\text { Rule systems tailored to managing and governing human and biophysical interactions } \\
\text { usually around common-pool resources }\end{array}$ & $\begin{array}{l}\text { Castilla and Fernandez (1998) } \\
\text { McGinnis and Ostrom (2013) }\end{array}$ \\
\hline GS1.1.1 Benthic marine & $\begin{array}{l}\text { Rule systems tailored to managing and governing human and biophysical interactions } \\
\text { of common-pool resources in the marine benthos }\end{array}$ & $\begin{array}{l}\text { Castilla and Fernandez (1998) } \\
\text { Aburto and Stotz (2013) } \\
\text { McGinnis and Ostrom (2013) }\end{array}$ \\
\hline GS2 - Geographic range & Spatial area where the rule system has effect or jurisdiction & $\begin{array}{l}\text { Castilla and Fernandez (1998) } \\
\text { McGinnis and Ostrom (2013) }\end{array}$ \\
\hline GS3 - Population & Population of actors on which the rule system has effect or jurisdiction & $\begin{array}{l}\text { Castilla and Fernandez (1998) } \\
\text { McGinnis and Ostrom (2013) }\end{array}$ \\
\hline \multicolumn{3}{|l|}{ GS4 - Regime type } \\
\hline GS4.1 Democratic & $\begin{array}{l}\text { Actors with authority to make decisions on behalf of the entire group of stakeholders } \\
\text { and elected to these positions through free voting processes }\end{array}$ & $\begin{array}{l}\text { Gelcich et al. (2008) } \\
\text { McGinnis and Ostrom (2013) }\end{array}$ \\
\hline GS4.2 Autocratic & $\begin{array}{l}\text { Actors with authority to make decisions on behalf of the entire group of stakeholders } \\
\text { are not elected by them }\end{array}$ & $\begin{array}{l}\text { Gelcich et al. (2010) } \\
\text { Basurto (2005) } \\
\text { McGinnis and Ostrom (2013) }\end{array}$ \\
\hline
\end{tabular}


Table A.3 (Continued)

\begin{tabular}{|c|c|c|}
\hline Attribute & Working definition & Reference \\
\hline GS5 - Organizations & $\begin{array}{l}\text { Types of institutions recognized by external actors and/or authorities that facilitate } \\
\text { formal structured interactions among actors affected by these institutions }\end{array}$ & McGinnis and Ostrom $(2013)^{\mathrm{b}}$ \\
\hline GS5.1 Government organizations & Institutions with governmental authority mandated to protect the public trust & $\mathrm{N} / \mathrm{A}$ \\
\hline GS5.1.1 Support enforcement & $\begin{array}{l}\text { Institutions with a mandate for monitoring and enforcement of rules to access and use } \\
\text { the resource }\end{array}$ & $\begin{array}{l}\text { Tan-Mullins (2007) } \\
\text { Hauck (2008) } \\
\text { Nasuchon and Charles (2010) }\end{array}$ \\
\hline GS5.1.2 Support funding & Institutions with a mandate to provide subsidies or credit & N/A \\
\hline GS5.1.3 Restoration efforts & $\begin{array}{l}\text { Institutions with a mandate to address provision problems such as the restocking of } \\
\text { natural populations }\end{array}$ & Carranza et al. (2009) \\
\hline $\begin{array}{l}\text { GS5.2 Non-government } \\
\text { organizations }\end{array}$ & Institutions without governmental authority mandated to protect the public trust & $\mathrm{N} / \mathrm{A}$ \\
\hline GS5.2.1 Capacity building & $\begin{array}{l}\text { Institutions with a mandate to increase the ability of resource users to govern their } \\
\text { resource units (e.g. govern access and use) }\end{array}$ & Mensah and Antwi (2002) ${ }^{b}$ \\
\hline GS5.2.2 Linking & $\begin{array}{l}\text { Institutions with a mandate for providing actors with access to resources or other actors } \\
\text { operating across governance scales }\end{array}$ & $\begin{array}{l}\text { Reis and D'Incao (2000) } \\
\text { Mahon et al. (2003) } \\
\text { Marin et al. (2012) }\end{array}$ \\
\hline GS5.2.3 Bridging & $\begin{array}{l}\text { Institutions with a mandate to provide actors with access to resources or other actors } \\
\text { operating within the same governance level }\end{array}$ & Marin et al. (2012) \\
\hline GS5.2.3.1 Unions & $\begin{array}{l}\text { An institution that establishes collective rights and responsibilities related to fishing } \\
\text { process, production, and social support }\end{array}$ & $\begin{array}{l}\text { Castilla et al. (1998) } \\
\text { Gelcich et al. (2010) }\end{array}$ \\
\hline GS5.2.3.2 Cooperatives & $\begin{array}{l}\text { An institution that establishes collective rights and responsibilities related to fishing } \\
\text { process and means of production }\end{array}$ & $\begin{array}{l}\text { Baticados et al. (1998) } \\
\text { Ponce-Díaz et al. (1998) }\end{array}$ \\
\hline GS6 - Rules-in-use & $\begin{array}{l}\text { Formal and informal rules in practice shaping human behavior and governing social } \\
\text { interactions. Usually there is a formal sanctioning mechanism if not followed }\end{array}$ & $\begin{array}{l}\text { Ostrom }(1990)^{b} \\
\text { Basurto }(2005)\end{array}$ \\
\hline GS6.1 Property rights & $\begin{array}{l}\text { Particular types of rules determining which actors have been authorized to carry out } \\
\text { which actions with respect to a specified good or service }\end{array}$ & McGinnis (2011) ${ }^{\text {b }}$ \\
\hline GS6.1.1 Open access & No effective restrictions on use of resources & McGinnis (2011) ${ }^{\mathrm{b}}$ \\
\hline $\begin{array}{l}\text { GS6.1.2 Moratory and } \\
\text { total allowable catch }\end{array}$ & $\begin{array}{l}\text { Access is restricted by size of the fleet, amount of total allowable catch, and/or } \\
\text { participating fishers }\end{array}$ & $\begin{array}{l}\text { Ramade-Villanueva et al. (1998) } \\
\text { Baine et al. (2007) } \\
\text { Hearn (2008) } \\
\text { Orensanz et al. (2013) }\end{array}$ \\
\hline GS6.1.3 Catch shares & $\begin{array}{l}\text { Access granted to communities, boat owners, or individual actors with clear entry and } \\
\text { exit rules }\end{array}$ & $\begin{array}{l}\text { Shivlani and Milon (2000) } \\
\text { González et al. (2006) } \\
\text { Orensanz et al. (2013) }\end{array}$ \\
\hline GS6.1.4 Territorial use privileges & $\begin{array}{l}\text { Area-based permanent or limited property rights granted to a formally or informally } \\
\text { organized group of fishers }\end{array}$ & Orensanz et al. (2013) \\
\hline GS6.1.4.1 Sea-bed tracts & $\begin{array}{l}\text { Sea-bed areas for which permanent or limited property rights are granted to fishers' } \\
\text { organizations and individuals }\end{array}$ & $\begin{array}{l}\text { Defeo and Castilla (2005) } \\
\text { González et al. (2006) } \\
\text { Ponce-Díaz et al. (2009) } \\
\text { Cudney-Bueno et al. (2009) } \\
\text { Orensanz et al. (2013) }\end{array}$ \\
\hline $\begin{array}{l}\text { GS6.1.4.2 Individually owned } \\
\text { fishing spots }\end{array}$ & $\begin{array}{l}\text { Human-constructed or agreed-upon areas for which permanent or limited property } \\
\text { rights are granted to individual fishers }\end{array}$ & $\begin{array}{l}\text { Seijo (1993) } \\
\text { Gelcich et al. (2006) } \\
\text { Orensanz et al. (2013) }\end{array}$ \\
\hline $\begin{array}{l}\text { GS6.1.4.3 Territorial use } \\
\text { communal rights }\end{array}$ & $\begin{array}{l}\text { Agreed-upon areas for which permanent or limited property rights are granted to all } \\
\text { members of a formal organization created for purposes other than fishing }\end{array}$ & $\begin{array}{l}\text { Glaser and da Silva Oliveira (2004) } \\
\text { Basurto (2005) } \\
\text { Beitl (2011) } \\
\text { Orensanz et al. (2013) }\end{array}$ \\
\hline GS6.2 Operational rules & $\begin{array}{l}\text { Implementation of practical decisions by individuals authorized (or allowed) to take } \\
\text { these actions }\end{array}$ & $\begin{array}{l}\text { Basurto (2005) } \\
\text { McGinnis (2011) }\end{array}$ \\
\hline GS6.3 Collective-choice rules & $\begin{array}{l}\text { The processes through which institutions are constructed and policy decisions made by } \\
\text { actors authorized (or allowed) to do so }\end{array}$ & $\begin{array}{l}\text { Cinti et al. (2010) } \\
\text { McGinnis (2011) }\end{array}$ \\
\hline GS6.4 Constitutional rules & $\begin{array}{l}\text { The process through which collective-choice procedures are defined and legitimized. } \\
\text { The process usually results in a state or federal fisheries guideline or law }\end{array}$ & $\begin{array}{l}\text { Gelcich et al. (2010) } \\
\text { McGinnis (2011) }\end{array}$ \\
\hline GS7 - Norms and strategies & $\begin{array}{l}\text { Human behavior shaped by beliefs, perceptions, and the biophysical setting. It governs } \\
\text { social interactions, but it is distinguished from rules in that there is no formal } \\
\text { sanctioning in place }\end{array}$ & $\begin{array}{l}\text { McGinnis }(2011)^{b} \\
\text { McGinnis and Ostrom (2013) }\end{array}$ \\
\hline GS8 - Network structure & $\begin{array}{l}\text { The connections among the rule-making organizations and the population subject to } \\
\text { these rules }\end{array}$ & McGinnis and Ostrom (2013) ${ }^{b}$ \\
\hline GS8.1 Horizontal & Link actors with each other to act collectively for a common purpose & Marin et al. (2012) \\
\hline GS8.2 Vertical & Link actors with other organizations or the state across levels & Marin et al. (2012) \\
\hline GS9 - Monitoring & $\begin{array}{l}\text { Local actors or those legitimized by them are responsible to observe and report changes } \\
\text { in the SES }\end{array}$ & Cox et al. (2010) ${ }^{b}$ \\
\hline GS9.1 Social & $\begin{array}{l}\text { Local actors, or outsiders legitimized by them, observe that other actors comply with } \\
\text { agreed-upon behavior in the use of the resource system and units }\end{array}$ & $\begin{array}{l}\text { Basurto (2005) } \\
\text { Cox et al. (2010) }\end{array}$ \\
\hline GS9.2 Biophysical & $\begin{array}{l}\text { Local actors, or outsiders legitimized by them, observe the condition of the resource } \\
\text { system and units }\end{array}$ & $\begin{array}{l}\text { Fernandez and Castilla (1998) } \\
\text { Lunn and Dearden (2006) } \\
\text { González et al. (2006) } \\
\text { Vasconcelos et al. (2008) } \\
\text { Cox et al. (2010) }{ }^{\text {b }}\end{array}$ \\
\hline GS10.1 Graduated sanctions & $\begin{array}{l}\text { Actors who violate operational rules are given a sanction coherent with its seriousness } \\
\text { and the times the offense has been committed }\end{array}$ & $\begin{array}{l}\text { Basurto (2005) } \\
\text { Gelcich et al. (2007) } \\
\text { Cudney-Bueno and Basurto (2009) }\end{array}$ \\
\hline GS10.2 Grim trigger strategies & Drastic sanctions that might withdraw all forms of cooperation with rule breaker & $\mathrm{N} / \mathrm{A}$ \\
\hline
\end{tabular}

${ }^{a}$ Defined as the prevailing set of processes or institutions through which the rules shaping the behavior of the actors are set and revised.

${ }^{b}$ Citation is not a benthic fisheries-specific paper but generally applicable and relevant to illustrate the concept and definition. 


\section{Table A.4}

Actors (A). ${ }^{a}$

\begin{tabular}{|c|c|c|}
\hline Attribute & Working definition & Reference \\
\hline A1 - Number of relevant actors & $\begin{array}{l}\text { Number of actors affecting decision-making processes related to harvesting in } \\
\text { the fishery }\end{array}$ & Mahon et al. (2003) \\
\hline \multirow[t]{5}{*}{ A2 - Socioeconomic attributes } & \multirow{5}{*}{$\begin{array}{l}\text { Characteristics of actors related to social and economic dimensions affecting } \\
\text { fishing dynamics }\end{array}$} & Tzanatos et al. (2006) \\
\hline & & Cinner and McClanahan (2006) ${ }^{\text {b }}$ \\
\hline & & Aburto et al. (2009) \\
\hline & & Kronen et al. (2010) \\
\hline & & Ünal and Franquesa (2010) \\
\hline \multirow{2}{*}{$\begin{array}{l}\text { A3 - History or past experiences } \\
\text { A3.1 Crisis }\end{array}$} & Past interactions that affect current actor's behavior and fisheries dynamics & $\mathrm{N} / \mathrm{A}$ \\
\hline & $\begin{array}{l}\text { Current use patterns triggered by a human or biophysically caused off- } \\
\text { patterned event }\end{array}$ & Gelcich et al. (2010) \\
\hline \multirow[t]{2}{*}{ A3.2 Duration } & \multirow{2}{*}{ Determined as the length of time the resource has been in use } & MacDonald (1982) \\
\hline & & Leiva and Castilla (2001) \\
\hline \multirow{2}{*}{ A4 - Location } & \multirow{2}{*}{$\begin{array}{l}\text { Physical place where the actors are in relation to the resource itself and the } \\
\text { market }\end{array}$} & Agrawal (2001) \\
\hline & & Agrawal and Chhatre (2006) ${ }^{\mathrm{b}}$ \\
\hline \multirow[t]{2}{*}{ A5 - Leadership/entrepreneurship } & \multirow{2}{*}{$\begin{array}{l}\text { Actors who have skills useful to organize collective action and are followed by } \\
\text { their peers }\end{array}$} & Cudney-Bueno and Basurto (2009) \\
\hline & & Gutiérrez et al. (2011) \\
\hline \multirow[t]{2}{*}{ A6 - Social capital } & \multirow{2}{*}{$\begin{array}{l}\text { Degree by which one or several individuals can draw upon or rely on others for } \\
\text { support or assistance in times of need }\end{array}$} & Gelcich et al. (2006) \\
\hline & & McGinnis (2011) ${ }^{\mathrm{b}}$ \\
\hline \multirow[t]{4}{*}{ A6.1 Trust and reciprocity } & \multirow{4}{*}{$\begin{array}{l}\text { Trust is a measure of the extent to which members of a community feel } \\
\text { confident that other members will live up to their agreements even if doing so } \\
\text { may not be in their immediate interest. Reciprocity is a symmetrical response to } \\
\text { a previous cooperative or defective action by a member of the community }\end{array}$} & Gelcich et al. (2006) \\
\hline & & Chapman et al. (2008) ${ }^{b}$ \\
\hline & & Schumann (2010) \\
\hline & & \\
\hline A7 - Knowledge of SES/mental models & $\begin{array}{l}\text { Degree to which stakeholders understand and make sense of the characteristics } \\
\text { and/or dynamics of the SES }\end{array}$ & Gelcich et al. (2008) \\
\hline A7.1 Mechanism to share & \multirow{3}{*}{$\begin{array}{l}\text { Actors' fishing practices allow them to learn characteristics of the resource at } \\
\text { sufficiently rapid rates leading to behaviors affecting the state of the resource }\end{array}$} & Foale (1998) \\
\hline \multirow{2}{*}{ knowledge about the fishery } & & Mahon et al. (2003) \\
\hline & & Hall and Close (2007) \\
\hline \multicolumn{3}{|l|}{ A8 - Importance of resource } \\
\hline A8.1 Economic dependence & $\begin{array}{l}\text { The resource constitutes a source of monetary income and plays a major role in } \\
\text { fishers' ability to sustain their livelihoods }\end{array}$ & Zúñiga et al. (2008) \\
\hline A8.2 Cultural dependence & $\begin{array}{l}\text { The resource constitutes a source of cultural values, practices, and services, and } \\
\text { plays a major role in the fishers' ability to sustain their livelihoods }\end{array}$ & Basurto (2005) \\
\hline \multicolumn{3}{|l|}{ A9 - Technologies available } \\
\hline \multirow[t]{3}{*}{ A9.1 Ownership of technology by fishers } & \multirow[t]{3}{*}{ Degree of fishing gear used by fishers owned by those same fishers } & Halafo et al. (2004) ${ }^{b}$ \\
\hline & & Basurto (2006) \\
\hline & & Eggert and Lokina (2007) ${ }^{\mathrm{b}}$ \\
\hline \multirow[t]{4}{*}{ A9.2 Homogeneity } & \multirow[t]{4}{*}{ Degree by which fishers use the same harvesting technology } & Defeo and Castilla (1998) \\
\hline & & Foale (1998) \\
\hline & & Basurto (2006) \\
\hline & & Narvarte et al. (2007) \\
\hline
\end{tabular}

a Defined as the characteristics of the individual or corporate users of the common-pool resource.

b Citation is not a benthic fisheries-specific paper but generally applicable and relevant to illustrate the concept and definition.

\section{References}

Aburto, J., Stotz, W., 2013. Learning about TURFs and natural variability: failure of surf clam management in Chile. Ocean and Coastal Management 71, 88-98.

Aburto, J., Thiel, M., Stotz, W., 2009. Allocation of effort in artisanal fisheries: the importance of migration and temporary fishing camps. Ocean and Coastal Management 52, 646-654.

Acheson, J.M., 2003. Capturing the Commons: Devising Institutions to Manage the Maine Lobster Industry. University Press of New England, Hanover, NH.

Acheson, J.M., Wilson, J.A., 1996. Order out of chaos. American Anthropologist 98 579-594.

Agrawal, A., 2001. Common property institutions and sustainable governance of resources. World Development 29, 1649-1672.

Agrawal, A., 2002. Common resources and institutional sustainability. In: Ostrom, E., Dietz, T., Dolšak, N., Stern, P.C., Stonich, S., Weber, E. (Eds.), The Drama of the Commons. National Academies Press, Washington, DC.

Agrawal, A., Chhatre, A., 2006. Explaining success on the commons: community forest governance in the Indian Himalaya. World Development 34, 149-166.

Anderies, J.M., Rodriguez, A.A., Janssen, M.A., Cifdaloz, O., 2007. Panaceas, uncertainty, and the robust control framework in sustainability science. Proceedings of the National Academy of Sciences 104, 15194-15199.

Bahre, C.J., Bourillón, L., Torre, J., 2000. The Seri and commercial Totoaba fishing (1930-1965). Journal of the Southwest 42, 559-575.

Baine, M., Howard, M., Kerr, S., Edgar, G., Toral, V., 2007. Coastal and marine resource management in the Galapagos Islands and the Archipelago of San Andres: issues, problems and opportunities. Ocean and Coastal Management $50,148-173$.

Baland, J., Platteau, J., 1996. Halting Degradation of Natural Resources: Is there a Role for Rural Communities? Oxford University Press, Oxford, England.

Basurto, X., 2005. How locally designed access and use controls can prevent the tragedy of the commons in a Mexican small-scale fishing community. Society and Natural Resources 18, 643-659.
Basurto, X., 2006. Commercial diving and the Callo de Hacha fishery in Seri territory. Journal of the Southwest 48, 189-209.

Basurto, X., 2008. Biological and ecological mechanisms supporting marine selfgovernance: the Seri Callo de Hacha fishery in Mexico. Ecology and Society 13 (2) 20., http://www.ecologyandsociety.org/vol13/iss2/art20.

Basurto, X., Cinti, A., Bourillón, L., Rojo, M., Torre, J., Weaver, H., 2012. The emergence of access controls in small-scale fisheries: a comparative analysis of individual licenses and common property rights from Mexico. Human Ecology 42, 597-609.

Basurto, X., Nenadovic, M., 2012. A systematic approach to studying fisheries governance. Global Policy 3, 222-230.

Basurto, X., Ostrom, E., 2009. Beyond the tragedy of the commons. Economia delle fonti di energia e dell'ambiente 52, 35-60.

Baticados, D.B., Agbayani, R.F., Gentoral, F.E., 1998. Fishing cooperatives in Capiz central Philippines: their importance in managing fishery resources. Fisheries Research 34, 137-149.

Beitl, C.M., 2011. Cockles in custody: the role of common property arrangements in the ecological sustainability of mangrove fisheries on the Ecuadorian Coast. International Journal of the Commons 5 (2), http://www.thecommonsjournal. org/index.php/ijc/article/view/URN\%3ANBN\%3ANL\%3AUI\%3A10-1-101644.

Berkes, F. (Ed.), 1989. Common Property Resources: Ecology and CommunityBased Sustainable Development. Belhaven Press, London, UK.

Berkes, F., 2006. From community-based resource management to complex systems: the scale issue and marine commons. Ecology and Society 11 (1) 45. http://www.ecologyandsociety.org/vol11/iss1/art45/.

Berkes, F., 2011. Restoring unity: the concept of marine social-ecological systems. In: Ommer, R.E., Perry, R.I., Cochrane, K., Cury, P. (Eds.), World Fisheries: A Social-Ecological Analysis. Wiley-Blackwell, Oxford, UK.

Blanco, E., 2011. A social-ecological approach to voluntary environmental initiatives: the case of nature-based tourism. Policy Sciences 44, 35-52.

Bourillón-Moreno, L., 2002. Exclusive fishing zone as a strategy for managing fishery resources by the Seri Indians, Gulf of California, Mexico. School of 
Renewable Natural Resources, University of Arizona, Tuscon, AZ (PhD dissertation).

Bromley, D.W., Feeny, D., McKean, M., Peters, P., Gilles, J., Oakerson, R., Runge, C.F., Thomson, J. (Eds.), 1992. Making the Commons Work: Theory, Practice, and Policy. ICS Press, San Francisco, CA.

Cabrera, J.L., Defeo, O., 2001. Daily bioeconomic analysis in a multispecific artisanal fishery in Yucatan, Mexico. Aquatic Living Resources 14, 19-28.

Carranza, A., Defeo, O., Beck, M., Castilla, J.C., 2009. Linking fisheries management and conservation in bioengineering species: the case of South American mussels (Mytilidae). Reviews in Fish Biology and Fisheries 19, 349-366.

Castilla, J.C., Bustamante, R., 1989. Human exclusion from rocky intertidal of Las Cruces, central Chile: effects on Durvillaea antartica (Phaeophyta, Durvilleales). Marine Ecology Progress Series 50, 203-214.

Castilla, J.C., Campo, M.A., Bustamante, R.H., 2007. Recovery of Durvillaea antartica (Durvilleales) inside and outside las cruces marine reserve, Chile. Ecological Applications 17, 1511-1522.

Castilla, J.C., Defeo, O., 2001. Latin American benthic shellfisheries: emphasis on comanagement and experimental practices. Reviews in Fish Biology and Fisheries $11,1-30$.

Castilla, J.C., Fernandez, M., 1998. Small-scale benthic fisheries in Chile: on comanagement and sustainable use of benthic invertebrates. Ecological Applications 8, S124-S132.

Castilla, J.C., Jerez, G., 1986. Artisanal fishery and development of a data base for managing the loco, Concholepas concholepas, resource in Chile. Canadian Special Publication of Fisheries and Aquatic Sciences 92, 133-139.

Castilla, J.C., Manriquez, P., Alvarado, J., Rosson, A., Pino, C., Espoz, C., Soto, R., Oliva, D., Defeo, O., 1998. Artisanal Caletas as units of production and co-managers of benthic invertebrates in Chile. Canadian Special Publication of Fisheries and Aquatic Sciences 125, 407-413.

Chapman, B., Jackson-Smith, D., Petrzelka, P., 2008. Comparative institutions and management resiliency in Latin American small-scale fisheries. Social Science Journal 45, 312-329.

Cinner, J.E., McClanahan, T.R., 2006. Socioeconomic factors that lead to overfishing in small-scale coral reef fisheries of Papua New Guinea. Environmental Conservation $33,73-80$

Cinner, J.E., McClanahan, T.R., MacNeil, M.A., Graham, N.A.J., Daw, T.M., Mukminin, A., Feary, D.A., Rabearisoa, A.L., Wamukota, A., Jiddawi, N., Campbell, S.J., Baird, A.H., Januchowski-Hartley, F.A., Hamed, S., Lahari, R., Morove, T., Kuange, J., 2012. Comanagement of coral reef social-ecological systems. Proceedings of the National Academy of Sciences 109, 5219-5222.

Cinner, J.E., Sutton, S.G., Bond, T.G., 2007. Socioeconomic thresholds that affect use of customary fisheries management tools. Conservation Biology 21, 1603-1611.

Cinti, A., Shaw, W., Cudney-Bueno, R., Rojo, M., 2010. The unintended consequences of formal fisheries policies: social disparities and resource overuse in a major fishing community in the Gulf of California, Mexico. Marine Policy 34, 328-339.

Cortez, T., Gonzalez, A.F., Guerra, A., 1999. Growth of Octopus mimus (Cephalopoda, Octopodidae) in wild populations. Fisheries Research 42, 31-39.

Cox, M., 2011. Advancing the diagnostic analysis of environmental problems. International Journal of the Commons 5, 346-363.

Cox, M., Arnold, G., Villamayor Tomás, S., 2010. A review of design principles for community-based natural resource management. Ecology and Society 15, 1-19.

Cudney-Bueno, R., Basurto, X., 2009. Lack of cross-scale linkages reduces robustness of community-based fisheries management. PLoS ONE 4, e6253.

Cudney-Bueno, R., Bourillón, L., Sáenz-Arroyo, A., Torre-Cosío, J., Turk-Boyer, P., Shaw, W.W., 2009. Governance and effects of marine reserves in the Gulf of California, Mexico. Ocean and Coastal Management 52, 207-218.

Daw, T.M., 2008. Spatial distribution of effort by artisanal fishers: exploring economic factors affecting the lobster fisheries of the Corn Islands, Nicaragua. Fisheries Research 90, 17-25.

Defeo, O., Castilla, J.C., 1998. Harvesting and economic patterns in the artisanal Octopus mimus (Cephalopoda) fishery in a northern Chile cove. Fisheries Research 38, 121-130.

Defeo, O., Castilla, J.C., 2005. More than one bag for the world fishery crisis and keys for co-management successes in selected artisanal Latin American shellfisheries. Reviews in Fish Biology and Fisheries 15, 265-283.

Dennis, D.M., Pitcher, C.R., Prescott, J.H., Skewes, T.D., 1992. Severe mortality in a breeding population of ornate rock lobster Panulirus ornatus (Fabricius) at Yule Island, Papua New Guinea. Journal of Experimental Marine Biology and Ecology $162,143-158$

Diele, K., Koch, V., Saint-Paul, U., 2005. Population structure, catch composition and CPUE of the artisanally harvested mangrove crab Ucides cordatus (Ocypodidae) in the Caete estuary, North Brazil: indications for overfishing? Aquatic Living Resources 18, 169-178.

Dietz, T., Dolsak, N., Ostrom, E., Stern, P.C., 2002. The drama of the commons. In: Ostrom, E., Dietz, T., Dolšak, N., Stern, P.C., Stonich, S., Weber, E. (Eds.), The Drama of the Commons. National Academies Press, Washington, DC.

Eggert, H., Lokina, R.B., 2007. Small-scale fishermen and risk preferences. Marine Resource Economics 22, 49-67.

Felger, R.S., Moser, M.B., 1985. People of the Desert and Sea: Ethnobotany of the Seri Indians. University of Arizona Press, Tucson, AZ.

Fernandez, M., Castilla, J.C., 1998. The Chilean artisanal Stone crab (Homalaspis plana) fishery: catch trends in open access zones and the effect of management areas in Central Chile. Journal of Shellfish Research 17, 285-291.

Fleischman, F., Boenning, K., Garcia-Lopez, G., Mincey, S., Schmitt-Harsh, M., Daedlow, K., Claudia Lopez, M., Basurto, X., Fischer, B., Ostrom, E., 2010. Disturbance, response, and persistence in self-organized forested communities: analysis of robustness and resilience in five communities in southern Indiana. Ecology and Society 15 (4) 9., http://www.ecologyandsociety.org/vol15/iss4/art9.

Foale, S., 1998. Assessment and management of the Trochus Fishery at West Nggela, Solomon Islands: an interdisciplinary approach. Ocean and Coastal Management 40, 187-205.

Folke, C., Hahn, T., Olsson, P., Norberg, J., 2005. Adaptive governance of socialecological systems. Annual Review of Environment and Resources 30, 441-473.

Froese, R., Kesner-Reyes, K., 2002. Impact of fishing on the abundance of marine species. In: ICES CM. , L:12.

Garrick, D., De Stefano, L., Fung, F., Pittock, J., Schlager, E., New, M., Connell, D., 2013. Managing hydroclimatic risks in federal rivers: a diagnostic assessment. Philosophical Transactions of the Royal Society A (in press).

Gelcich, S., Edwards-Jones, G., Kaiser, M.J., 2007. Heterogeneity in fishers' harvesting decisions under a marine territorial user rights policy. Ecological Economics 61, 246-254.

Gelcich, S., Edwards-Jones, G., Kaiser, M.J., Castilla, J.C., 2006. Co-management policy can reduce resilience in traditionally managed marine ecosystems. Ecosystems 9, 951-966.

Gelcich, S., Edwards-Jones, G., Kaiser, M.J., Watson, E., 2005. Using discourses for policy evaluation: the case of marine common property rights in Chile. Society and Natural Resources 18, 377-391.

Gelcich, S., Godoy, N., Castilla, J.C., 2009. Artisanal fishers' perceptions regarding coastal co-management policies in Chile and their potentials to scale-up marine biodiversity conservation. Ocean and Coastal Management 52, 424-432.

Gelcich, S., Hughes, T.P., Olsson, P., Folke, C., Defeo, O., Fernandez, M., Foale, S., Gunderson, L.H., Rodriguez-Sickert, C., Scheffer, M., Steneck, R.S., Castilla, J.C., 2010. Navigating transformations in governance of Chilean marine coastal resources. Proceedings of the National Academy of Sciences 107, 16794-16799.

Gelcich, S., Kaiser, M.J., Castilla, J.C., Edwards-Jones, G., 2008. Engagement in comanagement of marine benthic resources influences environmental perceptions of artisanal fishers. Environmental Conservation 35, 36-45.

Glaser, M., da Silva Oliveira, R., 2004. Prospects for the co-management of mangrove ecosystems on the North Brazilian coast: whose rights, whose duties and whose priorities? Natural Resources Forum 28, 224-233.

González, J., Stotz, W., Garrido, J., Orensanz, J., Parma, A., Tapia, C., Zuleta, A., 2006. The Chilean TURF system: how is it performing in the case of the loco fishery? Bulletin of Marine Science 78, 499-527.

Graen, G.B., Uhl-Bien, M., 1995. Relationship-based approach to leadership: development of leader-member exchange (LMX) theory of leadership over 25 years: applying a multi-level multi-domain perspective. Management Department Faculty Publications Paper 57, , http://digitalcommons.unl.edu/managementfacpub/57.

Guillou, M., Michel, C., 1993. Reproduction and growth of Sphaerechinus granularis (Echinodermata: Echinoidea) in southern Brittany. Journal of the Marine Biological Association of the United Kingdom 73, 179-192.

Gutiérrez, N.L., Hilborn, R., Defeo, O., 2011. Leadership, social capital and incentives promote successful fisheries. Nature 470, 386-389.

Guzmán, H.M., Tewfik, A., 2004. Population characteristics and co-occurrence of three exploited decapods (Panulirus argus, P. guttatus and Mithrax spinosissimus) in Bocas del Toro, Panama. Journal of Shellfish Research 23, 575-580.

Halafo, J.S., Hecky, R.E., Taylor, W.D., 2004. The artisanal fishery of Metangula, Lake Malawi/Niassa, East Africa. African Journal of Aquatic Science 29, 83-90.

Hall, G.B., Close, C.H., 2007. Local knowledge assessment for a small-scale fishery using geographic information systems. Fisheries Research 83, 11-22.

Hauck, M., 2008. Rethinking small-scale fisheries compliance. Marine Policy 32, 635-642.

Hearn, A., 2008. The rocky path to sustainable fisheries management and conservation in the Galápagos Marine Reserve. Ocean and Coastal Management 51, 567-574.

Hilborn, R., 2007. Managing fisheries is managing people: what has been learned? Fish and Fisheries 8, 285-296.

Holling, C.S., Berkes, F., Folke, C., 1998. Science, sustainability and resource management. In: Berkes, F., Folke, C. (Eds.), Linking Social and Ecological Systems: Management Practices and Social Mechanisms for Building Resilience. Cambridge University Press, Cambridge, UK.

Holling, C.S., Meffe, G.K., 1996. Command and control and the pathology of natural resource management. Conservation Biology 10, 328-337.

INEGI, 2005. XII Censo general de población y vivienda., http://www.inegi.gob.mx.

Ives, R.L., 1989. Land of Lava, Ash, and Sand: The Pinacate Region of Northwestern Mexico. Arizona Historical Society, Tuscon, AZ.

Johnson, T., Wilson, J., Cleaver, C., Vadas, R., 2012. Social-ecological scale mismatches and the collapse of the Maine sea urchin fishery. Ecology and Society 17 (2) 15., http://www.ecologyandsociety.org/vol17/iss2/art15/.

Kronen, M., Vunisea, A., Magron, F., McArdle, B., 2010. Socio-economic drivers and indicators for artisanal coastal fisheries in Pacific island countries and territories and their use for fisheries management strategies. Marine Policy 34, 1135-1143.

Leiva, G.E., Castilla, J.C., 2001. A review of the world marine gastropod fishery: evolution of catches, management and the Chilean experience. Reviews in Fish Biology and Fisheries 11, 283-300.

Lunn, K.E., Dearden, P., 2006. Monitoring small-scale marine fisheries: an example from Thailand's Ko Chang archipelago. Fisheries Research 77, 60-71.

MacDonald, C.D., 1982. Catch composition and reproduction of the Spiny lobster: Panulirus versicolor at Palau. Transactions of the American Fisheries Society 111, 694-699.

Madin, J.S., Bowers, S., Schildhauer, M.P., Jones, M.B., 2008. Advancing ecological research with ontologies. Trends in Ecology and Evolution 23, 159-168. 
Mahon, R., Almerigi, S., McConney, P., Parker, C., Brewster, L., 2003. Participatory methodology used for sea urchin co-management in Barbados. Ocean and Coastal Management 46, 1-25.

Mahon, R., McConney, P., Roy, R.N., 2008. Governing fisheries as complex adaptive systems. Marine Policy 32, 104-112.

Manriquez, P.H., Castilla, J.C., 2007. Roles of larval behaviour and microhabitat traits in determining spatial aggregations in the ascidian Pyura chilensis. Marine Ecology-Progress Series 332, 155-165.

Marin, A., Gelcich, S., Castilla, J.C., Berkes, F., 2012. Exploring social capital in Chile's coastal benthic comanagement system using a network approach. Ecology and Society 17 (1) 13., http://dx.doi.org/10.5751/ES-04562-170113.

McConney, P., Charles, A., 2010. Managing small-scale fisheries: moving towards people-centered perspectives. In: Grafton, R., Hilborn, R., Squires, D., Tait, M., Williams, M. (Eds.), Handbook of Marine Fisheries Conservation and Management. Oxford University Press, New York, NY

McGinnis, M.D., 2011. An introduction to IAD and the language of the Ostrom Workshop: a simple guide to a complex framework. Policy Studies Journal 39, 169-183.

McGinnis, M.D., Ostrom, E., 2013. SES framework: initial changes and continuing challenges. Ecology and Society. Special issue (in press).

McKean, M.A. 1992. Success on the commons: a comparative examination of institutions for common property resource management. Journal of Theoretical Politics 4, 247-281.

McKean, M.A., 2000. Common property: what is it, what is it good for, and what makes it work? In: Gibson, C., McKean, M., Ostrom, E. (Eds.), People and Forests: Communities, Institutions, and Governance. MIT Press, Cambridge, MA

Mensah, J.V., Antwi, B.K., 2002. Problems of artisanal marine fishermen in Ghana: the way ahead. Singapore Journal of Tropical Geography 23, 217-235.

Metaxatos, A., 2004. Population dynamics of the venerid bivalve Callista chione (L.) in a coastal area of the eastern Mediterranean. Journal of Sea Research 52, 293-305.

Moreno, C., Torre, J., Bourillón-Moreno, L., Durazo, M., Weaver, A.H., Barraza, R., Castro, R., 2005a. Estudio y Evaluación de la Pesquería de Callo de Hacha (Atrina tuberculosa) en la región de Bahía de Kino, Sonora y recomendaciones para su manejo. Guaymas Sonora: Comunidad y Biodiversidad, http://www.cobi.org.mx/index.php?pag=publicaciones\&idioma=esp.

Moreno, C., Weaver, A., Bourillón, L., Torre, J., Égido, J., Rojo, M., 2005b. Diagnóstico Ambiental y Socioeconómico de la Región Marina-Costera de Bahía de Kino, Isla Tiburón, Sonora México: Documento de trabajo y discusión para promover un desarrollo sustentable. Comunidad y Biodiversidad, A.C., Guaymas, Sonora. http://www.cobi.org.mx/index.php?pag=publicaciones\&idioma=esp.

Morsan, E., 2007. Spatial pattern, harvesting and management of the artisana fishery for purple clam (Amiantis purpurata) in Patagonia (Argentina). Ocean and Coastal Management 50, 481-497.

Moses, B.S., Udoidiong, O.M., Okon, A.O., 2002. A statistical survey of the artisanal fisheries of south-eastern Nigeria and the influence of hydroclimatic factors on catch and resource productivity. Fisheries Research 57, 267278.

Narvarte, M., González, R., Filippo, P., 2007. Artisanal mollusk fisheries in San Matías Gulf (Patagonia, Argentina): An appraisal of the factors contributing to unsustainability. Fisheries Research 87, 68-76.

Nasuchon, N., Charles, A., 2010. Community involvement in fisheries management: experiences in the Gulf of Thailand countries. Marine Policy 34, 163-169.

NRC (National Research Council), 1986. In: Proceedings of the Conference on Common Property Resource Management. National Academies Press, Washington, DC.

NRC (National Research Council), Ostrom, E., Dietz, T., Dolšak, N., Stern, P., Stonich, S., Weber, E., 2002. The Drama of the Commons. National Academies Press, Washington, DC.

Orensanz, J.M., Cinti, A., Parma, A.M., Burotto, L., Espinosa-Guerrero, S., SosaCordero, E., Sepúlveda, C., Toral-Granda, V., 2013. Latin-American rightsbased fisheries targeting sedentary resources. In: Orensanz, J.M., Seijo, J.C. (Eds.), Rights-based Management in Latin American Fisheries. , FAO Fisheries and Aquaculture Technical Paper 582 (in press).

Ostrom, E., 1990. Governing the Commons: The Evolution of Institutions for Collective Action. Cambridge University Press, New York, NY.

Ostrom, E., 2005. Understanding Institutional Diversity. Princeton University Press, Princeton, NJ.

Ostrom, E., 2007. A diagnostic approach for going beyond panaceas. Proceedings of the National Academy of Sciences 104, 15181-15187.

Ostrom, E., 2009. A general framework for analyzing sustainability of socialecological systems. Science 325, 419-422.

Ostrom, E., Cox, M., 2010. Moving beyond panaceas: a multi-tiered diagnostic approach for social-ecological analysis. Environmental Conservation 37 , 451-463.

Ostrom, E., Walker, J., Gardner, R., 1992. Covenants with and without a sword: selfgovernance is possible. American Political Science Review 86, 404-417.

Pauly, D., 2006. Major trends in small-scale marine fisheries, with emphasis on developing countries, and some implications for the social sciences. Maritime Studies (MAST) 4, 7-22.

Ponce-Díaz, G., Vega-Velázquez, A., Ramade-Villanueva, M., León-Carballo, G., Franco-Santiago, A.R., 1998. Socioeconomic characteristics of the abalone fishery along the west coast of the Baja California Peninsula, Mexico. Journal of Shellfish Research 17, 853-857.
Ponce-Díaz, G., Weisman, W., McCay, B., 2009. Co-responsibility and participation in fisheries management in Mexico: lessons from Baja California Sur. Pesca y Conservación 1, 14-22.

Prescott, R., Cudney-Bueno, R., 2008. Mobile 'reefs' in the northeastern Gulf of California: aggregations of black murex snails Hexaplex nigritus as habitat for invertebrates. Marine Ecology Progress Series 367, 185-192.

Ramade-Villanueva, M., Lluch-Cota, D.B., Lluch-Cota, S.E., Hernández-Vázquez, S Espinoza-Montes, A., Vega-Velázquez, A., 1998. An evaluation of the annual quota mechanism as a management tool in the Mexican abalone fishery. Journal of Shellifish Research 17, 847-851.

Reis, E.G., D'Incao, F., 2000. The present status of artisanal fisheries of extreme Southern Brazil: an effort towards community-based management. Ocean and Coastal Management 43, 585-595.

Salafsky, N., Salzer, D., Stattersfield, A.J., Hilton-Taylor, C., Neugarten, R., Butchart S.H.M., Collen, B.E.N., Cox, N., Master, L.L., O'Connor, S., Wilkie, D., 2008. standard lexicon for biodiversity conservation: unified classifications of threats and actions. Conservation Biology 22, 897-911.

San Martin, G., Parma, A., Orensanz, J., 2010. The Chilean experience with territorial user rights in fisheries. In: Grafton, H.R.Q., Squires, D., Tait, M., Williams, M. (Eds.), Handbook of Marine Fisheries Conservation and Management. Oxford University Press, New York, NY.

Santelices, B., Castilla, J.C., Cancino, J., Schmiede, P., 1980. Comparative ecology of Lessonia nigrescens and Durvillaea antartica (Pheophyta) in central Chile. Marine Biology 59, 119-132.

Scheffer, M., Rinaldi, S., Huisman, J., Weissing, F.J., 2003. Why plankton communities have no equilibrium: solutions to the paradox. Hydrobiologia 491, 9-18.

Schlager, E., 1994. Fishers' institutional responses to common-pool resource dilemmas. In: Ostrom, E., Gardner, R., Walker, J. (Eds.), Rules, Games, and CommonPool Resources. University of Michigan Press, Ann Arbor, MI.

Schumann, S., 2010. Application of participatory principles to investigation of the natural world: an example from Chile. Marine Policy 34, 1196-1202.

SECPLAC, 2005. Base de datos secretaría comunal de planificación. Illustre municipalidad de Navidad.

Seijo, J.C., 1993. Thalassorama: individual transferable grounds in a community managed artisanal fishery. Marine Resource Economics 8, 78-81.

Seijo, J.C., 2007. Considerations for management of metapopulations in small-scale fisheries of the Mesoamerican barrier reef ecosystem. Fisheries Research 87, $86-91$.

Sheridan, T.E., 1999. Empire of Sand: The Seri Indians and the Struggle for Spanish Sonora, 1645-1803. University of Arizona Press, Tucson, AZ

Shivlani, M.P., Milon, J.W., 2000. Sociocultural effects of a market-based fishery management program in the Florida Keys. Coastal Management 28, 133-147.

Smith, W.N., 1954. The Ethno-History of the Seri Indians 1890 to 1953. University of Arizona Library Special Collections, Tuscon, AZ.

Tan-Mullins, M., 2007. The state and its agencies in coastal resources management: the political ecology of fisheries management in Pattani, southern Thailand Singapore Journal of Tropical Geography 28, 348-361.

Tang, S.Y., 1992. Institutions and Collective Action: Self-Governance in Irrigation. ICS Press, San Francisco, CA.

Tzanatos, E., Dimitriou, E., Papaharisis, L., Roussi, A., Somarakis, S., Koutsikopoulos, C., 2006. Principal socio-economic characteristics of the Greek small-scale coastal fishermen. Ocean and Coastal Management 49, 511-527.

Ünal, V., Franquesa, R., 2010. A comparative study on socio-economic indicators and viability in small-scale fisheries of six districts along the Turkish coast. Journal of Applied Ichthyology 26, 26-34.

Urban, H.J., 1998. Description and management of a clam fishery (Gari solida, Psammobiidae) from Bahia Independencia, Peru (14 degrees S). Fisheries Research 35, 199-207.

Vasconcelos, P., Carvalho, S., Castro, M., Gaspar, M.B., 2008. The artisanal fishery for muricid gastropods (banded murex and purple dye murex) in the Ria Formosa lagoon (Algarve coast, southern Portugal). Scientia Marina 72, 287 298.

Villamayor-Tomas, S., 2012. Understanding robustness to disturbance through the theory of the commons: irrigation water governance and socio-ecological robustness in the Gallego and Cinca river watersheds, Spain. Indiana University (PhD dissertation).

Wade, R., 1994. Village Republics: Economic Conditions for Collective Action in South India. ICS Press, San Francisco, CA.

Wagner, J., Talakai, M., 2007. Customs, commons, property, and ecology: case studies from Oceania. Human Organization 66, 1-10.

Wilder, J.C.E., 2000. Seri hands: a special issue. Journal of the Southwest 42, 385-635.

Wilson, J., 2006. Matching social and ecological systems in complex ocean fisheries. Ecology and Society 11 (1) 9. http://www ecologyandsociety.org/vol11/iss1/art9/.

Young, O.R., 2002. Usable knowledge: design principles and institutional diagnostics. In: Young, O.R. (Ed.), The Institutional Dimensions of Environmental Change: Fit, Interplay, and Scale. MIT Press, Cambridge, MA

Young, O.R., King, L.A., Schroeder, H., 2008. Building regimes for socioecological systems: institutional diagnostics. In: Young, O.R., King, L.A., Schroeder, H. (Eds.), Institutions and Environmental Change: Principal Findings, Applications, and Research Frontiers. MIT Press, Cambridge, MA.

Zúñiga, S., Ramirez, P., Valdebenito, M., 2008. The socioeconomic situation in managed areas of the Coquimbo region, Chile. Latin American Journal of Aquatic Research 36, 63-81. 